\title{
The Macroeconomic Consequences of WAGE INDEXATION REVISITED
}

\author{
Esteban Jadresic \\ Central Bank of Chile
}

Since the mid-1970s, the macroeconomic consequences of wage indexation has been the subject of considerable research. Starting with an enthusiastic proposal for indexation by Friedman (1974) and two influential papers by Gray (1976) and Fischer (1977), the academic literature has examined the effects of wage indexation on the costs of disinflation and the level of inflation, the effects of wage indexation on the behavior of an economy hit by alternative types of shocks, the relation between wage indexation and exchange rate and monetary policy, the type of indexation indicators that are best suited for macroeconomic stability, and so on. The sizable literature that has emerged on the subject is reviewed by Carmichael, Fahrer, and Hawkins (1986), Aizenman (1987), Devereux (1994), Van Gompel (1994), Riveros (1996), and Landerretche, Lefort, and Valdés (in this volume).

Following Gray's (1976) analysis, most of the academic literature on this subject studies the effects of wage indexation under the key assumption that indexing is with respect to current inflation. This assumption implies that wage indexation helps to stabilize the real wage, which in standard models has strong implications on the behavior of the economy. For instance, it directly implies the wellknown proposition that wage indexation would help to maintain full employment when shocks are nominal and would exacerbate employment and output fluctuations when shocks are real. As emphasized by Fischer $(1977,1985,1988)$ and Simonsen (1983), however,

At the time of writing, Esteban Jadresic was affiliated with the International Monetary Fund.

I would like to thank Patricio Arrau, Eliana Cardoso, Miguel Kiguel, Fernando Lefort, Klaus Schmidt-Hebbel, and Peter Wickham for helpful comments.

Indexation, Inflation, and Monetary Policy, edited by Fernando Lefort and Klaus Schmidt-Hebbel, Santiago, Chile. (C) 2002 Central Bank of Chile. 
standard wage indexation is not based on current inflation. Indexed wage contracts typically adjust wages to the evolution of prices infrequently and with a lag, such that cost-of-living adjustments are determined according to lagged inflation rather than current inflation.

The fact that typical cost-of-living adjustments are based on lagged inflation is central because it implies that standard wage indexation defines a nominal rather than a real type of rigidity. As shown below, the basic implication of wage indexation to lagged inflation is a distinct and nontrivial dynamic behavior of nominal wages, stemming from both the direct effect of the indexation clauses and the indirect effect of those clauses on the outcome of wage negotiations. Because these mechanisms for wage adjustments can only respond to inflation with a lag, wage indexation need not stabilize or even affect the real wage, as the real wage can vary with changes in current inflation. ${ }^{1}$ Similarly, the aggregate consequences of wage indexation generally depend on the nature of monetary policy, among other factors. An obvious corollary is that there is no a priori reason why the effects of actual wage indexation should necessarily resemble those implied by the assumption that wages are indexed to current inflation.

Until recently, the formal academic literature has not explicitly explored the consequences of contracts that index wages to lagged inflation. As mentioned above, most of this literature assumes that wage indexation is based on current inflation. Moreover, while Fischer $(1977,1985,1988)$ examines in detail the effects of wage contracts with certain lagged indexation rules, the formulas he considers do not correspond to the typical indexation rule by which current wages are adjusted according to past inflation. Similarly, while Simonsen (1983) is persuasive in arguing that disinflation under lagged wage indexation is costly - unlike disinflation under perfect wage indexation-his formal model is not based on an explicit consideration of wage contracts indexed to lagged inflation. In consequence, his model cannot be used to compare the effects of indexed wage contracts with those of nonindexed wage contracts, which is the most relevant comparison in practice.

I attempt to fill part of the gap in the literature on wage indexation in three recent papers (Jadresic, 1996, 1998, 2002). These papers have in common the explicit modeling of wage indexation as a

1. For instance, in an economy in which labor productivity is constant and firms' individual demand curves are isoelastic, optimal price setting can imply a constant price-wage ratio regardless of whether wages are indexed or nonindexed. 
clause in long-term contracts that grants periodical cost-of-living adjustments according to the inflation rate cumulated since the last wage revision. In addition, they evaluate the consequences of wage indexation by comparing the behavior of the economy in the presence of contracts with indexation clauses against two main alternative standards of reference. The first is defined by the behavior of the economy under long-term contracts that specify preset time-varying wages during the life of each contract. The second yardstick is defined by the behavior of the economy under short-term contracts that specify fixed wages during the life of each contract.

This paper reviews the main lessons emerging from the above papers and explores a further implication of indexing wage contracts to lagged inflation, namely, the consequences of wage indexation during exchange-rate-based stabilization. While the paper provides some background to the issues being examined, it is not the intent here to provide a general review of the literature on wage indexation, which has been surveyed elsewhere. Rather, the focus of the paper is on the macroeconomic consequences of indexing wages to lagged inflation. The paper reviews the consequences of wage indexation to lagged inflation on the aggregate wage, the cost of disinflation under money- and exchange-rate-based stabilization, the variability of output under alternative types of shocks and policy regimes, the choice of exchange-rate regime, and the level and variability of inflation.

Two main lessons emerge from this review. First, the standard analysis of wage indexation in the academic literature provides a very misleading picture of the consequences of the typical type of wage indexation observed in real life. In particular, the assumption that wages are indexed to current inflation is of little usefulness even as a gross approximation of the issue. Second, taking into account the lags in actual wage indexation validates the views that most policymakers and applied observers seem to have on the consequences of wage indexation, although with some qualifications.

The paper is organized as follows. Following this introduction, section 1 briefly reviews previous approaches to model wage indexation. Section 2 presents the model of wage contracts indexed to lagged inflation in the papers mentioned above and two models of nonindexed wage contracts that can be used as benchmarks for comparison purposes. Sections 3 through 5 examine the implications of using these models on the macroeconomic issues listed above. Section 6 summarizes these implications and extracts the main lessons that emerge from the analysis. 


\section{Models OF WAGE INDEXation IN THE Previous Literature}

To avoid confusion, it is useful to pinpoint the meaning of wage indexation. The definition adopted here is provided by Aizenman (1987) in his survey article for the New Palgrave Dictionary of Economics: "Wage indexation is a mechanism designed to adjust wages to information that cannot be foreseen when the wage contract is negotiated. A wage contract with indexation clauses will specify the wage base (i.e., the money wage applicable in the absence of new information), the indexation formula that will be used to update wages, and how often updating will occur. Most traditional discussion has focused on wage indexation to the price level...."

According to this definition, the mere adjustment of wages to reflect inflation does not qualify as wage indexation. What is special about indexation is that it is a mechanism that enables wages to adjust to new information without the need to renegotiate the contract. If the adjustment of wages in line with inflation is due to the outcome of wage renegotiations or to a preset path of wage adjustments agreed at the time the contracts were signed, such adjustment in general cannot be attributed to wage indexation. To discern the effects of wage indexation, one should compare the effects of wage contracts that include indexation clauses against the effects of wage contracts without those clauses.

\subsection{Wage Indexation to Current Inflation}

Following Gray's (1976) original analysis, the standard model in the academic literature assumes that wage indexation adjusts wages according to the changes in the current price level. The model considers only one period, say period $t$. Right before the beginning of this period, wage contracts are negotiated. During the period, macroeconomic shocks are realized. Given a degree of indexation $\lambda$, the change in wages $\left(w_{t}\right)$ is assumed to be

$w_{t}=\lambda \pi_{t}$,

where $\pi_{t}$ is the inflation rate in period $t$. (Unless otherwise indicated, variables are hereafter measured in log terms, with lowercase letters representing their first differences and capital letters their levels.) 
Given this specification, the effects of wage indexation are studied by varying the degree of indexation. Under full wage indexation $\lambda$ is taken to be unit and the real wage is thus assumed to be fixed. The absence of indexation corresponds to $\lambda=0$, which assumes that without indexation the contract's nominal wage is fixed. Intermediate degrees of indexation correspond to partial wage indexation.

The direct implication of this approach is that wage indexation helps to stabilize the real wage. This effect might be irrelevant if the contracts negotiated between firms and workers are fully efficient. In standard macroeconomic models, however, in which these contracts establish wage conditions while employment is determined by labor demand, this increased real wage rigidity due to wage indexation has strong implications for the behavior of the economy. The best known is that wage indexation would stabilize output when shocks are nominal but destabilize output when shocks are real. Other implications are mentioned below.

\subsection{Lagged Wage Indexation}

The above approach is simple and has strong implications, but it has long been recognized that standard wage indexation is based on lagged rather than current inflation. Because of the lags in the availability of information about aggregate price indexes, actual cost-of-living adjustments due to indexation tend to be based on past inflation. Possibly more important, wage revisions due to indexation in practice are not done in every possible period. With infrequent indexation, even if current consumer price indexes (CPIs) were available in every period, wage adjustments are not proportional to current inflation, but rather to inflation cumulated since the last wage revision.

Despite the information lags and the infrequency of the costof-living adjustments, indexed contracts could approximately fix the real wage by establishing trigger-point indexation, a type of indexation in which wages are revised whenever accumulated inflation is larger than a given threshold. Similarly, indexed contracts could effectively fix the real wage by specifying ex post lump-sum payments between the parties so as to compensate them for the differences between past and actual inflation. In practice, however, trigger-point wage indexation seems to have been the exception, and indexed contracts with ex post compensations for 
changes in inflation rates have not been reported. The fact that actual indexed contracts do not attempt to really fix the real wage might well be a consequence of the problems highlighted by the literature on wage indexation to current prices.

Fischer (1977) was the first to attempt to formally model the consequences of lagged wage indexation. However, the indexing formula he examined in the main model of his paper is not the usual indexation rule by which current wages are adjusted to past inflation. Fischer assumed, rather, that indexed wages are set equal to the one-period-ahead expectation of the price level. In consequence, current wages in his model are adjusted according to the difference between the one-period-ahead expectations on the current and past price level. In the case of a two-period model, this wage adjustment rule can be written as

$w_{t}=\mathrm{E}_{t-1} P_{t}-\mathrm{E}_{t-2} P_{t-1}$,

where $P_{t-i}$ is the price level in period $t-i(i=0,1)$ and $\mathrm{E}_{t-j}$ is the expected value operator on the basis of information available at the end of period $t-j(j=1,2)$.

Fischer (1977) admits that the indexing formula he considers in that paper (and in Fischer, 1985) might be a far cry from the indexing formula used in practice. Thus it is not surprising that in a later paper, Fischer (1988) introduces an alternative indexation formula. His alternative formula, however, also differs from the usual rule by which wages are adjusted according to lagged inflation. Specifically, he considers contracts that last for two periods and assumes that indexed wages during the second period of the contract are set on the basis of the actual price level in the first period of the contract. He further assumes that wages during the first period of the contracts are set on the basis of the one-periodahead expectations of the price level during that period. This specification implies that the wage adjustment due to indexation in period $t$ is equal to the one-period-ahead prediction error of the first period of the contract:

$w_{t}=P_{t-1}-\mathrm{E}_{t-2} P_{t-1}$.

Thus the cost-of-living adjustment formula implied by this specification also differs from the usual rule by which wages are adjusted according to lagged inflation. 
Despite Fischer's formal attempts to model lagged wage indexation, the best-known reference on wage indexation to lagged inflation is probably Simonsen (1983). Simonsen's approach is to postulate a nominal wage adjustment rule of the form

$w_{t}=\lambda \pi_{t-1}+(1-\lambda) \mathrm{E}_{t-1} \pi_{t}+\mu \operatorname{Gap}_{t}$,

where $\operatorname{Gap}_{t}$ is the gap between actual and full-employment output and $\mu$ is a positive parameter. (For simplicity, I have dropped a term measuring the change in labor productivity included in Simonsen's original specification.) Simonsen interprets the first term of the right-hand side of equation 4 as the contribution of indexation to lagged inflation to the adjustment of wages, with $\lambda$ measuring the degree of wage indexation.

Simonsen's approach to wage indexation is used extensively in the applied literature on wage indexation, frequently under the assumption that $\mu=0$. It is not clear how to interpret his model, however, since equation 4 is not derived from an explicit analysis of the implications of alternative wage contracts. For instance, sizable empirical and analytical research is based on the assumption that aggregate inflation is determined by an expression similar to the right-hand side of equation 4 , in which the first and second terms are denominated by the backward-looking and forward-looking component of inflation, respectively. These models often interpret the backward-looking component of inflation as stemming from adaptive expectations rather than from indexation. Alternatively, this component could stem from other characteristics of the contracts and of the working of the economy. In Simonsen's model, there is no specific reason why the comparison of cases in which $\lambda=1$ or $\lambda>0$ with cases in which $\lambda=0$ would necessarily indicate anything about the consequences of having full or partial wage indexation versus no wage indexation. ${ }^{2}$

2. Below it becomes clear that the wage adjustment rule implied by the explicit consideration of contracts with indexation clauses differs from equation 4 . Indeed, while the first term on the right-hand side could be interpreted under certain assumptions as coming mainly from indexation clauses based on lagged inflation, the remainder of equation 4 does not appropriately capture the effects on wages of periodic contract renegotiation. One unappealing consequence of this specification problem is that according to equation 4, policymakers could maintain output permanently above full employment by engineering a continuously rising inflation rate. 
Other models of lagged wage indexation have been developed to analyze the consequences of centralized wage policies, but they typically refer to case-specific rules. Morandé (1985), for example, formally examines the consequences of a mandatory rule that imposes a floor on the base wage negotiated in collective agreements. Such a wage rule was applied in Chile at the beginning of the $1980 \mathrm{~s}$, but it was abolished in 1983 .

\subsection{Standards of Reference}

Evaluating the consequences of wage indexation requires not only specifying the nature of the adjustment of wages under indexation, but also defining the standard of reference against which those consequences are measured. In Gray's (1976) popular model, nonindexed wages are wages that remain fixed in nominal terms during the (only) period of reference. In Fischer's (1977, 1985 and 1988) analyses, in contrast, nonindexed wages correspond to wages that were preset in nominal terms when the contracts were signed, but that might be time varying. An example of this type of wage setting can be found in the unionized sector of the U.S. labor market, where three- or four-year contracts often specify a fixed wage increase every year. The differences in the standards of reference that can be used to evaluate the effects of wage indexation should be kept in mind in considering the analysis in the following sections.

\section{A Model of Wage Indexation to LAGGED INFLATION}

While the models of wage indexation presented in the previous section might be useful for some purposes, they do not model the consequences of wage contracts indexed to lagged inflation. This section presents a model that explicitly considers the consequences of this type of contract, as well as two models of nonindexed wage contracts that define alternative standards of reference for evaluating the effects of the indexed contracts. The analysis is based on the models developed in Jadresic (1991). Bonomo and García (1994) develop a model of wage indexation that is similar in spirit, but that incorporates continuous time and contracts granting only one cost-of-living adjustment during the life of each contract. 
They use their model to examine the effects of wage indexation during disinflation; I refer to their results below.

\subsection{A Model of Wage Contracts Indexed to Lagged Inflation}

This section focuses on the behavior of the aggregate wage. The analysis takes the structure of the contracts as given and assumes uniform staggering. Wage indexation is modeled explicitly as a contract clause that grants periodic adjustments in the contract wage according to a lagged value of the inflation cumulated since the last wage revision.

As mentioned above, indexed wage contracts generally do not provide full protection against fluctuations in the price level. Although they stipulate periodic wage revisions that depend on actual inflation, these revisions normally are not granted in every period and are based on a lagged value of the inflation cumulated since the previous wage adjustment. In Chile, for instance, where most wage contracts are indexed, cost-of-living adjustments are typically granted every six months based on 100 percent of the inflation cumulated since the last wage revision (Jadresic, 1992, 1995; Maturana, 1992; García, 1995). In the United States, indexed wage contracts observed in the unionized sector typically specify a quarterly or annual cost-of-living adjustment, based on a fraction of the inflation measured during the previous period (Hendricks and Kahn, 1985; Kaufman and Woglom, 1986). Because of delays in the availability of consumer price indexes, the cost-of-living adjustments in these countries are typically based on an $n$-month lagged value of cumulated inflation, with $n$ equal to one in the case of Chile and two or three in the case of the United States.

To model the consequences of indexing wages to lagged inflation, consider a group of wage contracts that last for $N$ periods and that contemplate cost-of-living adjustments based on 100 percent of past inflation every $n$ periods. Suppose that these contracts are renegotiated in a uniformly staggered fashion, and that $N / n$ is an integer larger than one, in accordance with what is seen in actual indexed contracts. Brief reasoning implies that in every period $1 / N$ of the wages are renegotiated, $1 / n-1 / N$ are adjusted according to the indexation clause, and $1-1 / n$ are kept unchanged. If the cost-of-living adjustments are defined in terms 
of inflation cumulated between the last wage increase and the last period before the adjustments, then the average wage increase in period $t$ is

$w_{t}^{I}=\left(\frac{1}{n}-\frac{1}{N}\right) \sum_{s=1}^{n} \pi_{t-s}+\frac{1}{N} x_{t}=\frac{1}{n} \sum_{s=1}^{n} \pi_{t-s}+\frac{1}{N}\left(x_{t}-\sum_{s=1}^{n} \pi_{t-s}\right)$,

where $x_{t}$ is the initial nominal increase of the wages renegotiated at time $t$. The superscript $I$ over $w_{t}$ denotes that this variable measures the change in the aggregate wage when contracts are indexed.

To complete the model of aggregate wage adjustment, one needs to specify what determines $x_{t}$. Extrapolating from simple studies of lagged wage indexation, one might be tempted to simply assume that the second term of the right-hand side of equation 5 is either a positive function of the output gap or merely a constant. If contracts are revised, however, $x_{t}$ must be agreed on in the wage negotiations between firms and workers.

To model $x_{t}$, I postulate that the outcome of the wage negotiations maximizes the expected value of a quadratic function of the average real wage implied by each contract. ${ }^{3}$ This specification implies that the initial nominal wage of each contract is set so as to make the expected value of the average real wage of the contract equal to a target real wage, with the latter depending on the wage setter's expectations for the exogenous variables that enter their objective function. If contracts that begin at time $t$ are negotiated with information on events that occurred up to time $t-1$, this can be written as $x_{t}$ is such that

$\mathrm{E}_{t-1}$ (contract's average real wage $)=\mathrm{E}_{t-1}\left(\frac{1}{N} \sum_{s=0}^{N-1} \Omega_{t+s}\right)$,

3. The goal of maximizing a nonlinear function of the real wage is implied by different microeconomic models of wage determination, including the union wage model and the efficiency wage model. The specification of the maximand as a quadratic function of the real wage is used to introduce expected variables in a log-linear manner and can be interpreted as a second-order approximation of the actual objective function. The assumption that the average real wage, rather than its present value, matters simplifies the algebra. 
where the right-hand expression represents the target real wage for the contracts signed for period $t$ to $t+N-1$ based on information available at the end of $t-1$. To simplify comparisons made below, this target real wage is specified as an average of period-specific target real wages $\mathrm{E}_{t-1} \Omega_{t+s}$ between $s=0$ and $s=N-1$. Defining precisely what determines the target real wage is not important here; this issue will be addressed below.

Given the structure of the contracts, this specification for the behavior of wage setters can be used to obtain expressions for $x_{t}$, as functions of past and current expectations about the target real wage and inflation in different dates and as functions of past inflation. The resulting expression can then be replaced in equation 5 to obtain an equation for aggregate wage adjustment. For space reasons, the derivation is not presented here (see Jadresic, 1996, for the derivation in the case $n=1$ ). The general solution is

$w_{t}^{I}=\frac{1}{N} \sum_{s=1}^{n} \pi_{t-s}+\frac{1}{N}\left(1-\mathrm{L}^{N}\right) \mathrm{E}_{t-1}\left\{\frac{1}{N} \sum_{s=0}^{N-1}\left[\Omega_{t+s}+\Phi_{n}(s) \pi_{t+s}\right]\right\}$,

where $\left[\Phi_{n}(s)\right]_{n=0}^{\infty}=\{n n-1 \ldots 1 n n-1 \ldots 1 \ldots\}$ and $\mathrm{L}$ is the standard lag operator.

The first term on the right-hand side of this equation captures the familiar link between current wage adjustments and past inflation that is associated with wage indexation to lagged inflation. In proportion $1 / n-1 / N$ this term stems from the indexation clauses contained in the contracts not revised during the reference period. In proportion $1 / N$ it also corresponds to a benchmark adjustment in the revised wage contracts, with respect to which a "plus" or "minus" initial adjustment is granted. In the aggregate, this term implies that the elasticity of current wage adjustment with respect to an unexpected shock in the last period's inflation rate is equal to $1 / n$.

The second term captures the effect of the initial wage revisions. These revisions can break the mechanical link between aggregate wage changes and past inflation. Whether this happens depends on the wage setters' target real wage and expected inflation during the life of the new contracts, as compared to the target real wage and inflation expectations they held when they signed the contracts that just ended. For example, if the inflation rate expected (at $t-1$ ) for the $n$ periods to come rises relative to the 
inflation rate that was expected (at $t-n-1$ ) for the last $n$ periods, then the aggregate wage will grow faster than past prices.

The second term on the right-hand side of equation 7 implies that the elasticity of the current aggregate wage with respect to a change in expected inflation is equal to $(n+1) / 2 N$. (This assumes that current and future inflation rates are all expected to change by the same amount.) This elasticity would be zero if wage indexation were relative to the current price level: in that case all the wage adjustments would be postponed until the changes in inflation actually occurred. This is not the case here, however, because with indexation to lagged inflation the anticipation of a permanent increase in inflation reduces the expected real wage and leads wage setters to grant larger initial wage increases; the size of this effect is proportional to $(n+1) / 2$. The impact of this effect at the aggregate level is multiplied by $1 / N$, as this effect is filtered by the fraction of contracts negotiated in each period.

\subsection{Alternative Standards of Reference}

Because wage indexing helps to prevent the cost of too frequent negotiations, in practice indexed wage contracts are longterm contracts; for instance, the typical duration of indexed contracts in the unionized sector of the U.S. labor market is three years or more, and in Chile it is two years. Different standards of reference can be used to evaluate the effects of these contracts. One possibility is to compare the indexed wage contracts against similarly long-term contracts that specify preset time-varying wages during the life of each contract, like the nonindexed contracts observed in the unionized sector of the U.S. labor market. Another possibility is to compare these indexed wage contracts against shorter-term contracts that specify a fixed wage during the life of each contract, like the one-year contracts that seem more common in the rest of the world.

\section{Contracts with Preset Time-Varying Wages}

Consider first the case in which the nonindexed contracts specify preset time-varying wages, such as Fischer's (1977) nonindexed contracts. In this case, wage setters can go beyond the attempt to achieve an average expected real wage and instead target a specific real wage for each period. With uniform staggering, this leads to 


$$
w_{t}^{P}=\frac{1}{N} \sum_{s=1}^{N} \mathrm{E}_{t-s}\left(\pi_{t}+\omega_{t}\right)+\frac{1}{N}\left(1-\mathrm{E}_{t-N-1}\right) \sum_{s=1}^{N}\left(\pi_{t-s}+\omega_{t-s}\right),
$$

where $\mathrm{E}_{t-s}{ }^{\omega}{ }_{t}$ is the expected change in the target real wage between $t-1$ and $t$ according to information at $t-s$, and so forth. The superscript $P$ over $w_{t}$ is used to denote that the change in the aggregate wage refers to contracts with preset time-varying wages. Here the length of these contracts is assumed to be the same as the length of the indexed contracts.

The first term on the right-hand side of equation 8 contains the adjustment of wages stemming from the changes in expected prices and the target real wage, according to the information that was available at the time the contracts were signed. The second term captures the effect of updating wages in the recently negotiated contracts, which depends on the discrepancy between the inflation rates and target real wages forecast in the previous negotiation with respect to their actual values.

In equation 8 , the elasticity of the current aggregate wage with respect to a shock in the previous period's inflation rate is smaller than before: $1 / N$ rather than $1 / n$. Also, if $n$ is larger than one, the elasticity of the current aggregate wage with respect to a shock in expected inflation is smaller: $1 / N$ rather than $(n+1) / 2 N$.

\section{Contracts with Fixed Wages}

Consider now the case of contracts in which wages remain fixed during the term of the agreement, as in Taylor's (1980) contracts. The length of these contracts is denoted by $M$. If staggering is uniform and if wage setters target an average real wage during the life of each contract, it can be shown that

$$
w_{t}^{F}=\frac{1}{M} \sum_{s=1}^{M} \pi_{t-s}+\frac{1}{M}\left(1-\mathrm{L}^{M}\right) \mathrm{E}_{t-1}\left\{\frac{1}{M} \sum_{s=0}^{M-1}\left[\Omega_{t+s}+(M-s) \pi_{t+s}\right]\right\},
$$

where the superscript $F$ over $w_{t}$ denotes that the change in the aggregate wage refers to contracts with fixed wages.

Equation 9 can be seen as a special case of equation 7 for indexed contracts, one in which the indexation period and the length of the contracts are identical and set equal to $M$. Accordingly, the 
first term on the right-hand side of this equation comes from a catch-up wage increase granted in the revised contracts, which compensates for the effect of inflation on the real value of the wages agreed in the negotiations held $M$ periods earlier. The second term corresponds to the wage increase above or below the catch-up term granted in the revised contracts.

There is the issue of defining the duration of the fixed wage contracts used for comparison purposes. In practice, since the duration of fixed wage contracts is usually shorter than the duration of indexed wage contracts, it is most relevant to consider cases where $M<N$. At the same time, since actual indexed contracts typically specify indexation periods equal to or shorter than one year, while the most common fixed wage contracts seem to have a duration of one year, it seems more relevant to consider cases where $M \geq n$. The research reviewed below focuses primarily on such cases, often assuming $M=N / 2$ and then exploring the consequences of alternative assumptions when relevant for the purposes at hand.

With this range for $M$, the elasticities of the current aggregate wage with respect to expected and past inflation under fixed wage contracts can be compared unambiguously with those under indexed contracts. First, equation 9 implies that the response of the current aggregate wage to the expectation of a permanent increase in inflation is proportional to $(M+1) / 2 M$, which for $M \leq N$ is always larger than the corresponding response in the case of indexed wage contracts. The intuition is that because fixed wage contracts are front loaded and do not offer any cost-of-living adjustments during their term, these contracts tend to be much more sensitive to changes in inflation expectations when they are renegotiated. Second, equation 9 implies that the response of the current aggregate wage to a shock in last period's inflation rate is proportional to $1 / M$, which for $M \geq n$ is always smaller or equal to the corresponding response in the case of indexed contracts.

Table 1 summarizes the elasticities of the current aggregate wage in response of a shock in the previous period's inflation rate and to a shock in expected inflation implied by the alternative wage contracts being considered.

\section{The Target Real Wage}

To model the determination of the target real wage, I have generally assumed that wage setters target a real wage that is equiproportional 
Table 1. Elasticity of the Current Aggregate Wage ${ }^{a}$

\begin{tabular}{lcc}
\hline Type of contract & $\begin{array}{c}\text { In response to a shock in } \\
\text { previous period's inflation }\end{array}$ & $\begin{array}{c}\text { In response to a shock in } \\
\text { expected inflation }\end{array}$ \\
\hline Indexed wages & $1 / n$ & $(n+1) / 2 N$ \\
Preset time-varying wages & $1 / N$ & $1 / N$ \\
Fixed wages & $(-)$ & $(-$ or $=)$ \\
& $1 / N$ & $(M+1) / 2 M$ \\
& $(-0 \mathrm{r}=)$ & $(+)$ \\
\hline
\end{tabular}

a. The signs in parenthesis indicate whether the elasticity is smaller than $(-)$, larger than (+) or equal to $(=)$ the corresponding elasticity for contracts with indexed wages. It is assumed that $n, N$, and $M$ are positive integers, and that $n \leq M<N$.

to the expected level of aggregate output (which, under the implicit assumption that the labor force is constant, is the same as the expected level of aggregate output per person in the labor force). Formally, this can be written as

$$
\mathrm{E}_{t-1} \Omega_{t+s}=\mathrm{E}_{t-1} Y_{t+s}
$$

where $Y_{t+s}$ is the level of aggregate output in period $t+s$.

This specification for the target real wage captures the intuition that the real wage tends to increase when the labor market becomes tighter and when the economy becomes richer. In addition, the specification is consistent with the theory and the empirical evidence. From a theoretical perspective, for a given size of the labor force, the assumption that the target real wage is proportional to the level of output is consistent with a supply-wage relation linking the real wage negatively with the rate of unemployment. As emphasized by Blanchard and Katz (1997), such a relation is implied by all the main modern approaches to wage determination based on explicit maximization models, including the matching approach, the efficiency wage approach, and the competitive approach. From an empirical perspective, in turn, the assumption that the target real wage is equiproportional to the expected level of output ensures that the rate of unemployment and the functional distribution of income in the models considered below are constant in the steady state; these features conform with the long-term evidence on these variables. Furthermore, the assumption of equiproportionality between output and the target real wage 
is consistent with the extensive empirical evidence on the wage curve compiled by Blanchflower and Oswald (1995). ${ }^{4}$

While this is a plausible specification for the target real wage, the driving force for the results presented below lies in the differences in the elasticities of the aggregate wage with respect to past and expected inflation implied by the different types of contract. It seems unlikely, therefore, that the essence of those results would be significantly altered by considering other plausible specifications for the target real wage. For instance, as noted below, assuming that the elasticity of the target real wage with respect to output is different from one tends to make no difference in the basic results.

\section{Wage Indexation AND the Cost of Disinflation}

It is apparent that the wage equations derived in the previous section can have very different consequences from those implied by the assumption that indexation is based on current inflation. But what precisely are those consequences? This section examines the effects of wage indexation on the cost of disinflation.

\subsection{Money-Based Stabilization}

There is a remarkable contrast between the views of academic researchers and those of policymakers on the effects of wage indexation on the cost of disinflation. On the one hand, the standard academic presumption since Friedman (1974) has been that price escalator clauses facilitate the end of inflation. This presumption is based on the notion that indexation speeds up the adjustment of wages to changes in inflation, and it is implied by the standard model of indexation to current inflation, as well as by the lagged wage indexation models generated by Fischer $(1985,1988)$. On the other

4. Their central finding from data for a number of regions and periods is that a 1 percent increase in the unemployment rate typically reduces the real wage by about 0.1 percent (Blanchflower and Oswald, 1995). With standard estimates for the Okun's Law coefficient of between 2 and 3 (for instance, see Adams and Coe, 1990) and an unemployment rate on the order of 5 percent, their finding implies that a 1 percent increase in aggregate output would raise the real wage on the order of 1 percent. 
hand, as highlighted by Simonsen (1983) and Williamson (1985), policymakers have generally contended that wage indexation causes inflationary inertia and thus makes disinflation more difficult. For instance, the economic authorities in Chile recently pointed to wage indexation to explain why faster disinflation was not possible in the country, and wage indexing was prohibited in Argentina and Brazil during recent stabilization programs. ${ }^{5}$

Until recently, the only published paper to explicitly evaluate the consequences of indexation to lagged inflation during disinflation was Bonomo and García (1994). ${ }^{6}$ These authors replicate Ball's (1990) analysis of credible disinflation policies in a closed economy with staggered fixed prices, but they expand the model by adding an indexation rule according to which, at the midpoint of the period between successive price revisions, individual prices are adjusted by the inflation cumulated since the last price revision. As in Ball's earlier work, Bonomo and García (1994) find that certain gradual disinflation policies could cause a boom in the economy if they were credible; under indexation, however, the boom caused by those policies would be followed by a recession, such that the net output gain during the disinflation would be smaller in the indexed economy than in the economy modeled by Ball. They also estimate that the time necessary to reduce inflation without affecting output would be longer in the indexed economy.

Bonomo and García's findings suggest that wage indexation could make disinflation harder. However, since their analysis focuses on gradual and credible policies that cause net booms rather than net recessions, it really does not evaluate whether indexation makes disinflation more costly. Perhaps most important, the paper provides no obvious explanation for the contrasting academic and policymakers' views on the effects of indexation on the cost of disinflation.

To shed light on these issues, Jadresic (1996) examines the costs of disinflation implied by wage equations similar to those presented in the previous section. As in most of the prior literature, the paper focuses on the output loss caused by money-based stabilization. Its results fully dispel the notion that wage indexation necessarily raises or lowers the cost of disinflation, and it

5. For a brief review of the literature on the effects of wage indexation on the cost of disinflation, see the introduction in Jadresic (1996).

6 . Formally, they referred to price indexation rather than wage indexation, but this difference is insubstantial. 
provides a suitable explanation for the difference between the views of academics and policymakers on the effects of wage indexation on disinflation. The analysis shows that the cost of disinflation in an economy with indexed wage contracts tends to be smaller than in an economy with preset time-varying wage contracts, but larger than in an economy with short-term fixed wage contracts. Thus it turns out that the academic and policymakers' views can both be appropriate depending on the standard of reference used to evaluate the effects of wage indexation. ${ }^{7}$

To illustrate this result, figure 1 shows the behavior of output and inflation implied by the wage equations 7, 8, and 9 after a sudden reduction of money growth, under the simple assumptions that price inflation is equal to wage inflation $\left(\pi_{t}=w_{t}\right)$, and that aggregate output growth is determined by

$y_{t}=m_{t}-\pi_{t}$,

where $m_{t}$ is the growth rate of money. The figure assumes that the cut in money growth is unanticipated but permanent (equal to 0.01 in log terms) and that $N=4, n=1$. The short-term fixed wage contracts assume $M=N / 2=2$. (The less relevant case of $M=N$ is discussed in Jadresic, 2002; it is omitted here for space reasons.)

Figure 1 shows that the net output loss during disinflation is largest when contracts specify preset time-varying wages, smallest when contracts are short-term and specify fixed wages, and intermediate when contracts contain indexation clauses. Note that the cost of disinflation with indexed wage contracts appears to be smaller than with preset time-varying wages.

Disinflation policies with more complex paths for the growth rate of money can eliminate the boom shown above by the indexed economy. For instance, with a monetary policy designed to obtain a linear disinflation in the indexed economy, this economy displays no boom following the recovery but enjoys a faster disinflation and thus a faster recovery to full employment. The path of

7. This explanation accords with the fact that much of the academic literature refers to the United States-where contracts with preset time-varying wages abound in the unionized sector of the labor market and thus seem a relevant yardstick for evaluating the effects of wage indexation-while the policymakers' view alludes essentially to other countries, where fixed wage contracts often provide a more appropriate standard of reference. 


\section{Figure 1. Output during Money-Based Stabilization: Closed Economy}

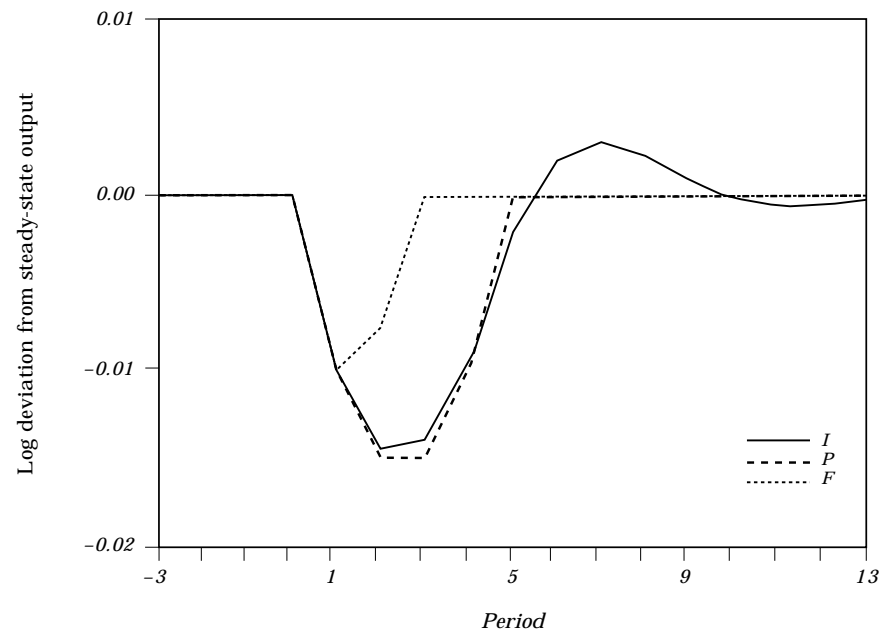

output and inflation during disinflation can also differ from the one depicted in figure 2 for several other reasons, including if there is only partial credibility, if the disinflation is anticipated, if there is a procyclical ratio between prices and wages, if the real wage targeted by wage setters depends on output with an elasticity different from unity, if money demand is interest elastic, and if the economy is open. (The latter case is shown in figure 2, using the model and base case parameters presented below.) The analysis in Jadresic (1996) indicates, however, that the ranking of disinflation costs mentioned above is quite robust under these alternative circumstances: the net output loss during the disinflation tends to be smaller in the indexed economy than in the economy with preset time-varying wage contracts and larger than in the economy with short-term fixed wage contracts.

What is the source of the discrepancies in the behavior of the economies with and without indexation? The answer to this question lies in the different elasticities for the current aggregate wage implied by the contracts under consideration. 
Figure 2. Output during Money-Based Stabilization: Open Economy

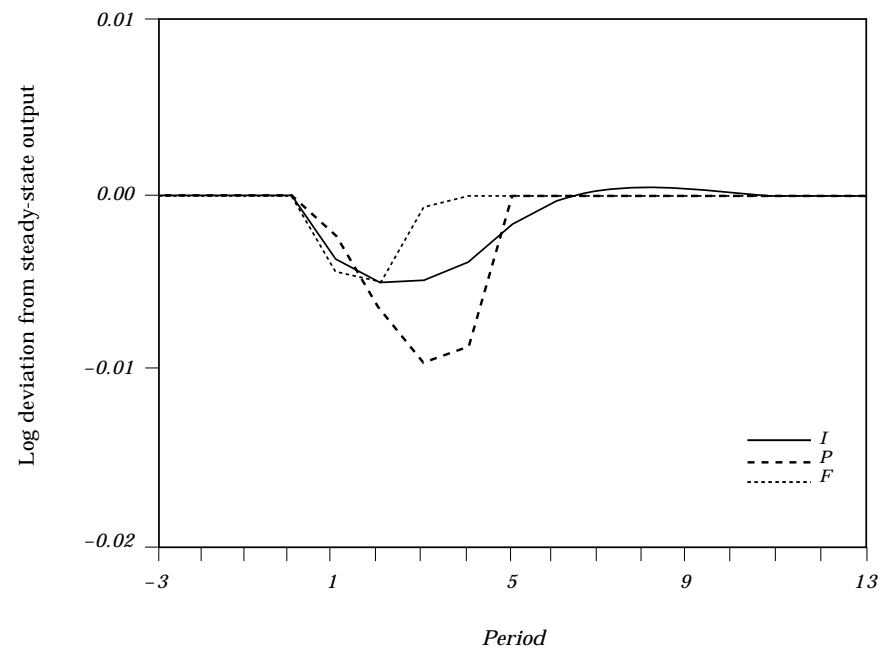

Compare first the elasticities of the aggregate wage under indexed wage contracts with the elasticities of the aggregate wage under contracts that specify preset time-varying wages. As noted above and shown in table 1, the elasticity of the aggregate wage in response to changes in the past period's inflation rate is always larger when wages are indexed. During disinflation, this feature implies that once initial reductions in the inflation rate have been achieved, the existence of indexation feeds a larger part of those reductions back into wages and inflation in following periods. In comparison with an economy featuring contracts that specify preset time-varying wages, this enhanced feedback from recent inflation to current inflation can permit a faster recovery, create a boom following the recession, or prevent a larger drop of output during the recession caused by the cut in money growth. As a result, the output cost of disinflation in the indexed economy tends to be smaller.

The favorable consequence of indexation for the cost of disinflation due to the effect just described can be reinforced if the indexation period is longer than the basic period in which the preset time-varying wages are kept fixed (in the model, if $n>1$ ). 
If this is the case, the aggregate wage under indexation is not only more responsive to past inflation, but also more responsive to changes in expected inflation. In comparison with an economy characterized by preset time-varying wages, this effect directly helps to break the inflationary inertia in the indexed economy at the beginning of the disinflation and, as a result, also helps to reduce the output cost of disinflation. ${ }^{8}$

Compare now the elasticities of the aggregate wage under indexed wage contracts with the elasticities of the aggregate wage under fixed wage contracts. As noted above and shown in table 1, the elasticity of the aggregate wage in response to a shock in expected inflation is always smaller when wages are indexed. This implies that wage indexation makes it harder to break the initial inflationary inertia of the economy and thus it tends to deepen the recession associated with a sudden reduction in money growth. Unless some other force dominates, it follows that wage indexation raises the cost of disinflation when indexed wage contracts are compared with fixed wage contracts.

Note, however, that the elasticity of the aggregate wage in response to the past period's inflation rate is larger when wages are indexed if the length of the fixed wage contracts used as the standard of reference is longer than the length of the indexation period, for instance, if the fixed wage contracts have the same duration as the indexed contracts. This observation raises the question of whether, in this case, the enhanced feedback from past to current inflation caused by wage indexation can more than compensate for the adverse effect of indexation on the cost of disinflation caused by the smaller responsiveness of wages to the expected disinflation. In Jadresic (1996), I find that this can be the case if the fixed wage contracts used as the standard of comparison have the same duration as the indexed wage contracts and if the economy is such that early in the disinflation there is a sizable fall in prices independent of wages-stemming, for instance, from a large appreciation of the domestic currency or a sharp drop in marginal costs. However, when the standard of reference is a fixed wage contract half as long as the indexed contract and twice as long of the indexation period, the result that wage indexation raises the cost of disinflation emerges unchanged in the simulations, even in the case of disinflation with sizable initial falls in prices independent

8. This effect is not considered in Jadresic (1996), which assumes $n=1$. 
of wages. More generally, of course, the basic result can always be preserved by using a standard of reference based on short-term fixed wage contracts whose length is equal to or shorter than the indexation period of the indexed contracts. ${ }^{9}$

To summarize, wage indexation can raise or lower the net output loss caused by money-based stabilization depending on the standard of reference. In comparison with contracts specifying preset time-varying wages, indexed wage contracts reduce the cost of disinflation; this is mainly because indexation establishes an automatic feedback from past to current inflation that facilitates disinflation once initial reductions in inflation have been achieved. In comparison with short-term contracts specifying fixed wages, in turn, indexed wage contracts tend to raise the cost of disinflation because indexation reduces the responsiveness of wages during the early stages of disinflation.

\subsection{Exchange-Rate-Based Stabilization}

The theoretical literature on wage indexation dedicates little specific attention to the effects of wage indexation during exchangerate-based inflation stabilization. ${ }^{10}$ In this case, however, the Gray (1976) model clearly implies that wage indexation would make disinflation easier. For example, with full wage indexation to current inflation, pegging the exchange rate should stop inflation abruptly and without costs. As in the case of money-based disinflation, this

9. To provide an example of the relative elasticities of indexed and fixed wage contracts, consider the case of Chile. Typical indexed wage contracts last for twentyfour months and have an indexation period of six months (with 100 indexation to lagged inflation); the implied elasticities of the current aggregate wage with respect to the inflation rate in the past period and expected inflation are 0.167 and 0.146 , respectively. Suppose that the alternative to these contracts are fixed wage contracts that last for twelve months. In this case, the elasticities of the current aggregate wage with respect to inflation in the past period and to expected inflation are 0.083 and 0.542 , respectively. Thus the elasticity of the aggregate wage with respect to past inflation for the indexed contracts is twice as large as the same elasticity for the fixed wage contracts, and the elasticity of the aggregate wage with respect to expected inflation for the indexed contracts is close to one-fourth of the same elasticity for the fixed wage contracts.

10. A sizable theoretical literature addresses the relation between wage indexation and monetary and exchange rate policies in open economies, but this literature focuses on other issues (see next section and the surveys listed in the opening paragraph). This gap contrasts with the significant attention that exchange-rate-based stabilization has received elsewhere in the academic literature since the early $1980 \mathrm{~s}$. For a review and assessment of the different approaches used in the latter literature, see Rebelo and Végh (1995). 
prediction again stands in sharp contrast with the view of policymakers and applied observers, who tend to believe that wage indexation makes disinflation harder during exchange-rate-based stabilization. For instance, the ban on wage indexation in Brazil and Argentina mentioned above was implemented in a context of exchange-rate-based stabilization plans. ${ }^{11}$

This section explores whether the consequences of wage indexation during a money-based stabilization described above also apply in the context of an exchange-rate-based stabilization. The analysis is based on a Mundell-Fleming economy characterized by a domestic and a foreign good that are imperfect substitutes and by a domestic and a foreign bond that are perfect substitutes. The notation for the variables in this economy is as follows: $y_{t}$ measures the growth rate of aggregate domestic output; $p_{t}$ is the rate of change in the price of the domestic good in terms of domestic currency; $\pi_{t}$ denotes the inflation rate; $i_{t}$ represents the nominal interest rate of the domestic bond; $m_{t}$ is the growth rate of the domestic money supply; and $s_{t}$ indicates the devaluation rate of the domestic currency. It is assumed that foreign variables are constant in level. The following relations hold in this economy:

$$
\begin{aligned}
& y_{t}=-\beta(1-\mathrm{L})\left(i_{t}-\mathrm{E}_{t} \pi_{t+1}\right)+\gamma\left(s_{t}-p_{t}\right), \\
& m_{t}-\pi_{t}=y_{t}-\delta(1-\mathrm{L}) i_{t}, \\
& p_{t}=w_{t}+\alpha y_{t}, \\
& \pi_{t} \equiv \varepsilon p_{t}+(1-\varepsilon) s_{t}, \text { and } \\
& i_{t}=\mathrm{E}_{t} s_{t+1}
\end{aligned}
$$

where $\alpha, \beta, \gamma, \delta$, and $\varepsilon$ are nonnegative parameters.

Equations 12 through 16 represent, respectively, the principle of effective demand in the market for the domestic good, the money

11. The policymaker's view is often illustrated with the aid of Simonsen's (1983) wage equation described above, under the assumption that $\mu=0$, and an additional inflation equation of the type $\pi_{t}=\eta w_{t}+(1-\eta) s_{t}$, where $s_{t}$ is the devaluation rate of the domestic currency and $\eta$ is a parameter between zero and one (see Edwards, 1996, for a recent example). This framework directly implies that pegging the exchange rate when wages are indexed reduces inflation slowly and at the cost of a real appreciation (because it implies $\pi_{t}=\lambda \eta \pi_{t-1}$ and $s_{t}-\pi_{\mathrm{t}}=-\lambda \eta \pi_{t-1}$ ). As noted above, however, this approach does not permit an explicit comparison of the effects of indexed and nonindexed wage contracts, and thus it should only be considered as illustrative of the policymaker's concern. 
market equilibrium condition, the pricing equation for the domestic good, the definition of inflation as a weighted average of the rate of change in the price of domestic and foreign goods in domestic currency, and the uncovered interest parity condition for the domestic and the foreign bonds. Equations 12 and 15 implicitly assume the law of one price for the foreign good.

Figure 3 combines equations 12 through 16 with the wage equations presented above to show the effects of an unanticipated, credible reduction in the devaluation rate. The economy is assumed to have been in a steady state with persistent inflation before the new policy is implemented, at time $t=1$. The output path depicted for each type of contract corresponds to a base case in which $\alpha=0$, which captures the stylized fact that output does not have strong effects on prices, given wages (Blanchard and Fischer, 1989, pp. 464-67). This base case also assumes $\beta=0.5, \gamma=0.3, \delta=0.5$, and $\varepsilon=0.7$, which are comparable in order of magnitude with those considered by Fischer (1988) and Henderson and McKibbin (1993). Also, the base simulations assume $N=4$ and $n=1$, with the shortterm fixed wage contracts half as long as the indexed contracts. The experiment considers a reduction in the rate of devaluation equal to 0.01 in $\log$ terms.

\section{Figure 3. Output during Exchange-Rate-Based Stabilization:} Base Case

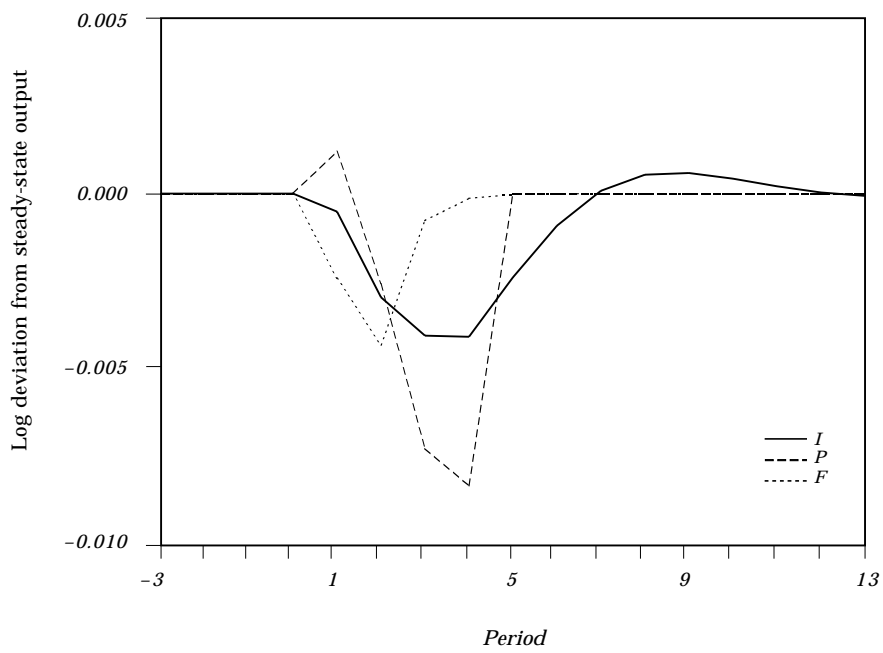


Figure 3 shows that with the base-case parameters, the basic outcome of a sudden reduction of the rate of devaluation is a recession. This result is similar to that found for a money-based stabilization, although now the overall output loss is smaller (compare figure 3 with figure 2; see also table 2) and in the case of contracts with preset time-varying wages, the economy experiences a short-lived initial boom. Most importantly for the purposes of this paper, the figure suggests that the ranking of the disinflation costs is the same as in the case of a money-based stabilization; that is, the largest net output loss occurs when contracts specify preset time-varying wages, the smallest occurs when contracts are short-term and specify fixed wages, and an intermediate level occurs when contracts are indexed. This perception is confirmed by the numerical net output loss reported in the first row of table 2 .

To clarify this result, figures 4 and 5 consider two special cases that permit the separation of the two channels through which the

\section{Table 2. Net Output Loss during Exchange-Rate- Based Stabilization ${ }^{a}$}

\begin{tabular}{lccc}
\hline Parameter & Indexed wages & $\begin{array}{c}\text { Preset time-varying } \\
\text { wages }\end{array}$ & Fixed wages \\
\hline Base model $^{\mathrm{b}}$ & 1.32 & 1.69 & 0.76 \\
$\beta=0$ & 1.26 & 1.58 & 0.54 \\
$\gamma=0$ & 0.35 & 0.35 & 0.35 \\
$\beta=1$ & 1.50 & 1.89 & 1.61 \\
$\gamma=0, \beta=1$ & 0.70 & 0.70 & 0.70 \\
$\gamma=1$ & 3.75 & 5.03 & 1.99 \\
$\alpha=0.5$ & 1.08 & 1.47 & 0.64 \\
$\varepsilon=0.5$ & 1.16 & 1.64 & 0.69 \\
$\mathrm{~N}=2$ & 0.77 & 0.81 & 0.55 \\
$\mathrm{~N}=2, \gamma=0$ & 0.35 & 0.35 & 0.35 \\
$\mathrm{~N}=8$ & 2.63 & 4.91 & 1.45 \\
$\mathrm{~N}=8, \gamma=0$ & 0.35 & 0.35 & 0.35 \\
Net output loss during money-based stabilization $^{\mathrm{c}}$ & & \\
Base model $^{\mathrm{b}}$ & 1.80 & 2.72 & 1.01 \\
\hline
\end{tabular}

a. Sum of log deviation of output from steady-state level in response to a reduction in the devaluation rate of 0.01 in log term (x 100).

b. Assumes $\alpha=0, \beta=0.5, \gamma=0.3, \delta=0.5, \varepsilon=0.7, N=4$, and $n=1$.

c. Sum of log deviation of output from steady-state level in response to a reduction in money growth of 0.01 in $\log$ term (x 100). 
exchange-rate-based stabilization affects aggregate demand. First, figure 4 shows that when demand responds only to the real exchange rate $(\beta=0)$, the exchange-rate-based stabilization causes a recession. This is because the gradual adjustment of wages and inflation causes the reduction of the devaluation rate to trigger a temporary real appreciation of the domestic currency, which reduces the demand for domestic output during the adjustment process. Second, figure 5 shows that when demand responds only to the real interest rate $(\gamma=0)$, the exchange-rate-based stabilization can cause a boom-recession cycle, as noted by Rodriguez (1982) and Dornbusch (1982). This is because the fixing of the exchange rate can reduce the real interest rate during the early stages of the disinflation-as it fixes the nominal interest rate in an inflationary context-which must fall below its steady-state level to reestablish the equilibrium real exchange rate.

The evaluation of the net output losses with and without wage indexation in these two special cases is revealing. When aggregate demand depends only on the real exchange rate, the ranking of

\section{Figure 4. Output during Exchange-Rate-Based Stabilization: Demand Elastic to Real Exchange Rate Only}

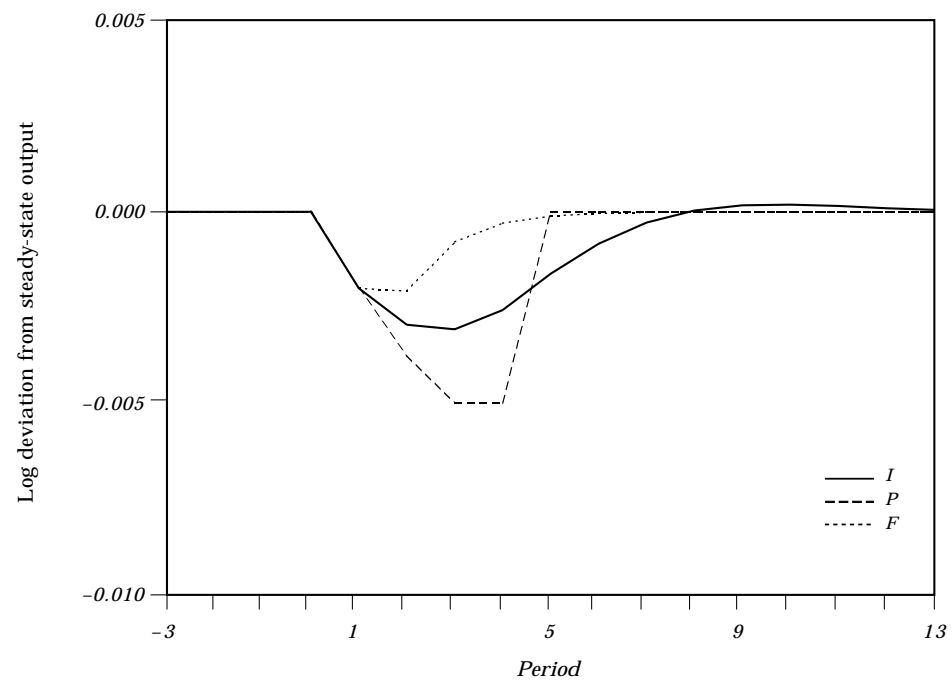




\section{Figure 5. Output during Exchange-Rate-Based Stabilization:} Demand Elastic to Real Interest Rate Only

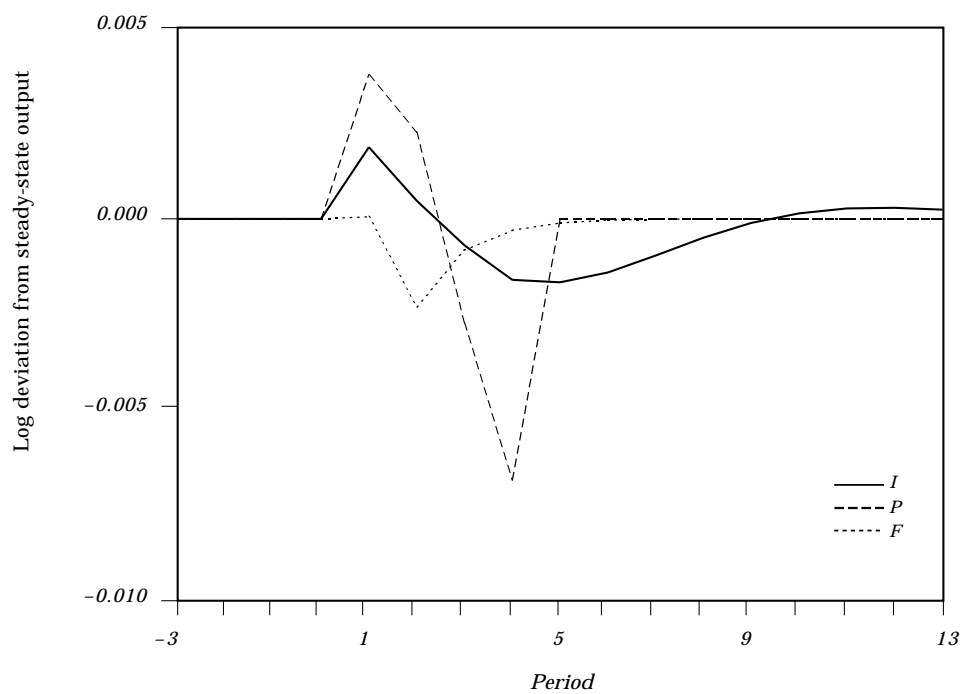

these losses is as above; that is, indexed wage contracts reduce the cost of disinflation relative to preset time-varying wage contracts and increase it relative to short-term fixed wage contracts (second row of table 2). When aggregate demand depends only on the real interest rate, in turn, the net output losses are identical regardless of the type of wage contracts prevailing in the economy (third row of table 2). This implies that wage indexation influences the cost of disinflation only through its effect on the size of the real appreciation of the domestic currency. Inasmuch as the elasticity of the aggregate wage to the expected disinflation is larger when contracts are indexed than when contracts specify preset time-varying wages, it is not surprising that indexed wage contracts reduce the cost of disinflation relative to those contracts. By a similar reasoning, it is not surprising that indexed contracts increase the cost of disinflation relative to short-term fixed wage contracts.

This paper offers no general proof that the above finding should always obtain, but the simulation results reported in table 2 suggest that this finding is robust to alternative parameter specifications. More generally, it seems clear that to the extent that output is 
adversely affected by a real appreciation of the domestic currency, the basic effect of wage indexation described in the previous paragraph will be preserved. I thus conclude that the qualitative effects of wage indexation on the cost of disinflation under an exchange-rate-based stabilization are likely to be similar to those under a money-based stabilization: indexed wage contracts tend to lower the cost of disinflation relative to preset time-varying wage contracts and raise it relative to short-term fixed wage contracts.

\section{Wage IndeXation AND OUtPut Stability}

The previous section examined the consequences of wage indexation in the context of a change in policy regime, characterized by a change in the growth rate of money or in the devaluation rate. Most of the academic literature on wage indexation, however, focuses on the consequences of wage indexation when the economy is hit by exogenous shocks, for a given policy regime. This section reviews the effects of wage indexation to lagged inflation in such a context, focusing on its impact on output stability.

\subsection{The Gray-Fischer Proposition Revisited}

Despite the sizable literature that has accumulated on the topic, the major academic proposition on wage indexation continues to be that originally stated by Gray (1976) and Fischer (1977): indexing wages stabilizes output when shocks are nominal and destabilizes output when shocks are real. Following Gray, the standard argument in support of this proposition hinges on the assumption that wage indexation is based on current inflation. Fischer's analysis of the lagged indexation rule described by equation 2 also supports this proposition. While Fischer admits that such an indexing formula may be a far cry from the indexing formula used in practice and mentions that indexing to lagged inflation could modify his conclusion that wage indexation stabilizes output in the face of nominal shocks if shocks are transitory, he conjectures that if the nominal shocks are permanent, his basic conclusion should be preserved. He does not address this issue formally.

In Jadresic (2002), I reexamine the effects of wage indexation on output stability in an economy similar to that considered by Gray and Fischer, but using wage equations similar to the ones derived 
above. Following their analysis, I consider a closed economy in which the exchange rate plays no important role and focus mainly on the case in which the policy regime features a fixed money supply. To solve the problem analytically, I also assume that indexed and preset time-varying wage contracts have a duration of two periods, while fixed-wage contracts have a duration of one period, equal to the indexation period. For comparison, Gray's contracts are one-period contracts, while Fischer's contracts are twoperiod contracts in the case of nonindexed contracts and an undetermined number of periods in the case of indexed contracts.

The main result stemming from Jadresic (2002) is that in Gray and Fischer's economy, wage indexation to lagged inflation tends to destabilize output regardless of whether shocks are nominal or real. This appears to be true both when indexed wage contracts are compared with short-term fixed wage contracts and, under plausible parameter values, when they are compared with preset time-varying wage contracts.

To illustrate this result, consider an economy in which the rate of change of aggregate output is determined by the rate of change of the real money supply and a nominal shock $\mathrm{v}_{t}$ that is independent and serially uncorrelated, with mean zero and variance $\sigma_{\mathrm{v}}{ }^{2}$. This shock can be interpreted as a permanent, unanticipated shock reduction in money demand. Given the assumption that the monetary authority follows a fixed money supply rule, this specification implies that

$y_{t}=-\pi_{t}+\mathrm{v}_{t}$.

Also assume that inflation is determined by the simple relationship

$\pi_{t}=w_{t}-u_{t}$

where $u_{t}$ is a real shock at period $t$, assumed to be independent and serially uncorrelated, with mean zero and variance $\sigma_{u}^{2}$. This shock can be interpreted as an unexpected and permanent increase in the level of productivity. ${ }^{12}$

Equations 17 and 18 can be solved for each type of contract by combining them with the corresponding wage equation, with $N=2$

12. This is a simplified version of the inflation equation considered in Jadresic (2002), which in addition includes the term $\alpha\left(y_{t}-u_{t}\right)$ in its right-hand side, where $\alpha$ is the elasticity of prices, given wages. This term is omitted here for simplicity, as the stylized fact seems to be $\alpha \approx 0$ (Blanchard and Fischer, 1989, pp. 464-67). See the discussion below. 
and $n=M=1$, and making the rational expectations assumption that the policy regime of a fixed money supply is well known and that actors know the structure of the economy. The paper's main interest here is the behavior of the output gap $\left(G a p_{t}\right)$, which is defined as the difference between the actual and the frictionless level of output, with the latter being the level of output that would be observed if wages were fully flexible and the current shocks were fully observable. ${ }^{13}$ Solving for this variable leads to the following stochastic difference equations:

$\operatorname{Gap}_{t}^{I}=\frac{2}{5} G a p_{t-1}^{I}-\frac{1}{5} G a p_{t-2}^{I}+\mathrm{v}_{t}+\frac{1}{5} \mathrm{v}_{t-1}+\frac{2}{5} u_{t-1}$

$\operatorname{Gap}_{t}^{P}=\mathrm{v}_{t}+\frac{1}{2} \mathrm{v}_{t-1}$, and

$\operatorname{Gap}_{t}^{F}=\mathrm{v}_{t}$,

where the meaning of the superscripts is obvious.

The behavior of the output gap in response to real and a nominal shocks implied by these equations is depicted in figures 6 and 7. Consider first the case of a nominal shock. The initial impact of such a shock is identical regardless of the type of wage contract. This result arises because, independently of the type of contract considered, wages in any given period are predetermined. Consequently, a positive shock $v_{t}$ tends to increase real money balances and output identically. Because of the assumption that prices do not respond directly to output, inflation is not modified at the time of the impact and output increases precisely by the amount of the shock.

In subsequent periods, the effects of a nominal shock do depend on the nature of the contracts in the economy. The quickest adjustment of output to equilibrium occurs when short-term fixed wage contracts prevail; in this case the initial expansion of output lasts only for the period of the impact. When preset timevarying wage contracts prevail, one-half of the initial expansion of output persists one period after the impact; thereafter the economy rests in equilibrium. Finally, in the case of indexed contracts, three-fifths of the initial expansion of output persists one period

13. In the model presented here, the frictionless level of output is proportional to the level of productivity. Indeed, with fully adjusting wages and perfect information, wage setters would set $w_{t}=\pi_{t}+y_{t}$; this equation and equation 18 together imply that the rate of change of the frictionless level of output is $u_{t}$. 
Figure 6. Output Effects of a Nominal Shock in a Closed Economy with a Fixed Money Supply

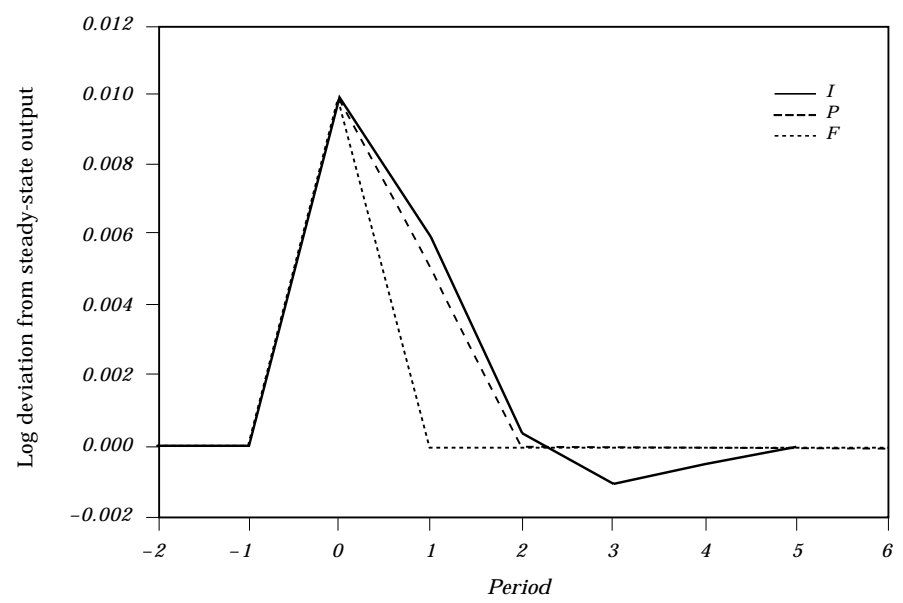

Figure 7. Output Effects of a Real Shock in a Closed Economy with a Fixed Money Supply

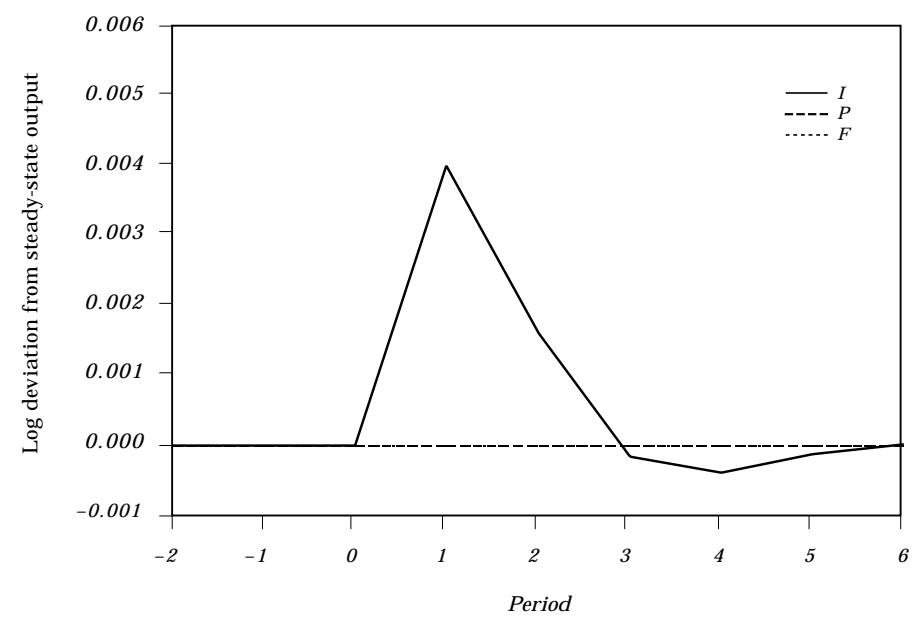


after the shock; thereafter output converges to its equilibrium through an oscillatory process that rapidly fades away. ${ }^{14}$

Any reasonable measure of instability demonstrates that these results imply an unambiguous overall effect of wage indexation on the response of output to the nominal shock: wage indexation destabilizes output. What is the intuition? In comparison with shortterm fixed wage contracts, indexed wage contracts imply a slower return of output to its equilibrium level; that is, the indexation clauses do not provide a mechanism to compensate for the fact that with longer contracts, a smaller fraction of wages are revised in every period. In comparison with preset time-varying wage contracts, the reason is more subtle: since the indexation clauses automatically transmit part of the increase in wages and inflation from one period to the other, wage setters respond to a positive nominal shock to the economy by anticipating that in subsequent periods inflation will stay temporarily above the trend and that real money balances and output will continue to fall; the anticipation of falling output moderates the adjustment of wages and inflation during the first period after the impact, which slows down the economy's adjustment and causes the initial expansion of output to persist.

Consider now the case of a real shock. As shown in figure 7 , such a shock has no impact on the output gap in the period in which it affects the economy. Given that in any single period wages are predetermined, a positive real shock, $u_{t}$, reduces prices proportionally and increases real money balances and output exactly by the same magnitude as the size of the shock. Because output and the frictionless level of output increase by the same amount, the output gap remains unaltered. While this result differs from the expansive effect implied by the positive nominal shock considered above, this outcome again does not depend on the type of contract considered.

In subsequent periods, output remains in equilibrium under short-term fixed and preset time-varying wage contracts, but with indexed wage contracts, output is destabilized: there is a boom in the first period after the shock, and thereafter output converges gradually to its equilibrium level. The boom occurs because the reduction in the inflation rate in the period of the shock is transmitted automatically into an inflation rate that is lower than

14. The oscillatory and convergent nature of the evolution of output can be verified by computing the roots of the characteristic equation implied by equation 19, which are imaginary and have the property that the multiplication of their inverses is less than one. 
the trend in the next period; this effect raises real money balances and expands output despite the fact that no additional shocks have occurred (in the simple model considered here, the size of the output gap in the period following the shock is two-fifths of the magnitude of the shock). In the next period, upward pressure on wages increases inflation and moves real money balances and output toward their equilibrium levels. Thereafter, output converges to its equilibrium after a sequence of oscillations that gradually fade away. ${ }^{15}$

In the context of Gray and Fischer's specific closed-economy model, Jadresic (2002) shows that the findings that wage indexation to lagged inflation generally destabilizes output tend to be robust to considering a more general inflation equation, which allows for a direct effect of output on prices, given wages. For nominal shocks, the caveat is that if this effect is positive and strong enough, wage contracts indexed to lagged inflation can stabilize output relative to preset timevarying wage contracts-although they would continue to destabilize output relative to short-term fixed wage contracts. In the case of real shocks, wage indexation would always be destabilizing.

These findings are not robust, however, to alternative assumptions about the nature of the economy. As discussed in the following section, considering an open economy can fully reverse these findings. Allowing for alternative monetary policies can also have significant effects. For instance, the analysis in Jadresic (2002) shows that if money supply is indexed to lagged inflation rather than being fixed, the variability of output with indexed wage contracts is reduced to the same level as the variability of output with contracts that specify preset time-varying wages under a fixed money supply. One implication of this result is that even if the economy is hit only by real shocks, wage indexation does not necessarily destabilize output. Of course, the drawback of indexing the money supply is that such a policy dramatically destabilizes inflation.

\subsection{Output Stability in the Open Economy}

Analyzing the effects of wage indexation on output stability in a closed economy can be useful for academic purposes, and it can be appropriate for understanding the behavior of economies with

15. As in the case of a nominal shock, this process of adjustment can be verified by computing the roots of the characteristic equation associated with equation 19 . 
a small external sector or with a financial sector that is poorly integrated into the international financial markets and that applies a crawling peg. For most countries today, however, it would be more relevant to discuss the effects of wage indexation in the context of an open economy. I do so in Jadresic (1998), with the help of the simple model presented above for analyzing exchange-rate-based stabilization. This section reviews some of the implications of that analysis. Since the focus now is not only on evaluating the overall effects of wage indexation on output stability, but also on exploring more generally the effects of wage indexation on output behavior, I start by providing some background.

The literature on international macroeconomics demonstrates substantial agreement on the behavior of an open economy hit by aggregate shocks under perfect capital mobility and simple nominal price or wage rigidities. The basic common principles are contained in the Mundell-Fleming results, according to which a monetary shock destabilizes output when the exchange rate floats but does not affect it when the exchange rate is fixed, while a shock on the demand for goods destabilizes output more when the exchange rate is fixed than when it floats. More generally, there is a consensus that in a conventional open economy, the response of output and other macroeconomic variables to aggregate shocks depends crucially on the exchange rate regime in place. ${ }^{16}$

According to the literature on wage indexation, however, indexing wages can cause the behavior of an open economy to be very different from that just described. ${ }^{17}$ The sharpest contrast arises under the assumption of full wage indexation, in which case nominal wages are assumed to move proportionally with the current price level and the real wage is thus deemed fixed. In conventional models a fixed real wage makes the level of output independent from nominal variables, and it follows that in this case the MundellFleming results cease to hold: monetary shocks do not affect output even if the exchange rate is flexible, while shocks on the demand for goods affect output identically with a fixed and a floating exchange

16. The seminal references on the behavior of an open economy with nominal rigidities are Fleming (1962), Mundell (1963), and Dornbusch (1976). A useful survey of the related literature can be found in Marston (1985). For an analysis using a representative agent framework, see Obstfeld and Rogoff (1996).

17. On the effects of wage indexation in open economies, in addition to the general surveys on wage indexation mentioned in the introduction, see Genberg (1989), Argy (1990), and Turnovsky (1995). 
rate. More generally, full wage indexation would make the exchange rate regime totally irrelevant for output behavior. ${ }^{18}$

Once the lags in actual indexation rules are taken into account, however, it becomes apparent that wage indexation does not have the effects mentioned in the previous paragraph. The analysis in Jadresic (1998) confirms this presumption. By running simulations based on the open economy model and on the wage equations presented in the previous sections, the paper finds that when the lags in actual indexation are considered, wage indexation to lagged inflation affects output behavior substantially less than posited by the previous academic literature. In particular, wage indexation does not appear to invalidate or modify the Mundell-Fleming results or to blur the behavior of output across exchange rate regimes. Rather, the response of output to a variety of shocks appears to be qualitatively similar and of the same order of magnitude regardless of the type of contract prevailing in the economy.

These results are illustrated in figures 8 and 9. These figures show the response of output to a monetary and a demand shock implied by the open economy model of the previous section and the wage equations presented above. The shocks correspond to a permanent, unexpected reduction in the demand for money and a permanent, unexpected increase in aggregate demand for the domestic output, respectively. As before, the simulations assume that the respective policy regime and the structure of the economy are well known by the actors. The floating exchange rate regime corresponds to the assumption $m_{t}=0$, and the fixed exchange rate regime to $s_{t}=0$. The shocks are equivalent to 0.01 in log terms and the parameter values are those of the base case already defined.

Consider first the case of a monetary shock. The top panel of figure 8 shows the response of output when the exchange rate floats. Output tends to expand temporarily regardless of the type of contract prevailing in the economy. The basic reasons are familiar.

18. When the academic literature refers to partial wage indexation, the contrast with the conventional predictions are less acute, but qualitatively the differences remain. In this case, nominal wages are taken to move less than proportionally with the current price level, but the real wage is still assumed to be more rigid than without wage indexation. In standard models, this increased real wage rigidity lessens the effects of monetary shocks on output when the exchange rate is flexible, and it dampens the effect of shocks in the demand for goods on output when the exchange rate is fixed. The general proposition is that the larger the degree of wage indexation, the smaller are the differences on output behavior across exchange rate regimes (Marston, 1982; Turnovsky, 1983). 
First, the monetary shock reduces nominal interest rates and raises expected inflation, cutting down expected real interest rates. Second, the shock depreciates the domestic currency, which increases the competitiveness of the economy given predetermined wages and prices. Both effects tend to boost demand and output.

The top panel of figure 8 clearly shows that wage indexation to lagged inflation does not insulate output from the monetary shock. This result is partly explained by the fact that with wages indexed to lagged inflation, the depreciation of the domestic currency caused by the monetary shock affects future wages but does not affect current wages. Because of this initial predetermination of wages, the temporary rise in the competitiveness of the economy and the temporary reduction in expected real interest rates occur despite the existence of wage indexation. In principle, however, the evolution of indexed and nonindexed wages following the period of the shock could be sufficiently different as to substantially alter the behavior of output, both during and after the shock. In this regard, the top panel of figure 8 shows that, perhaps not surprisingly, the adjustment of output to its steady-state level takes longer with indexed contracts than with short-term fixed wage contracts. Also, output with indexed contracts does not stabilize completely once all contracts have been revised; it converges cyclically to the steady-state level. In all cases, however, the overall response of output to the monetary shock is qualitatively similar, and the effects are comparable in order of magnitude.

Nonetheless, does indexing wages to lagged inflation at least help to reduce its variability? The simulations for alternative parameter values in Jadresic (1998) indicate that the answer is ambiguous and depends crucially on the specific characteristics of the economy. The ambiguity is closely related to the size of the depreciation of the domestic currency due to the monetary shock and its initial impact on prices and inflation. If these effects are large enough, the indexation clauses imply a relatively large adjustment of wages in the period after the shock occurs, and indexed wage contracts can contribute to accelerating the process of adjusting wages, prices, and output. If these effects are small-for instance, because the weight of foreign goods in the CPI is low or because aggregate demand is very sensitive to the real interest rate or the real exchange rate-then indexed contracts can destabilize output. Because indexed wage contracts automatically feed back part of the initial increase in wages and inflation to subsequent 
periods, they tend to reduce expected real interest rates and thus make the initial expansion of output more persistent. In addition, indexed contracts tend to generate excessive cumulated inflation in later periods, which elevates nominal and real interest rates, reduces competitiveness, and can drive output below its steady-state level. Both effects work to increase the variability of output.

Figure 9 shows the case of a shock in the demand for the domestic good. Given the nominal rigidity introduced by the wage

Figure 8. Output Effects of a Monetary Shock in an Open Economy

Floating exchange rate

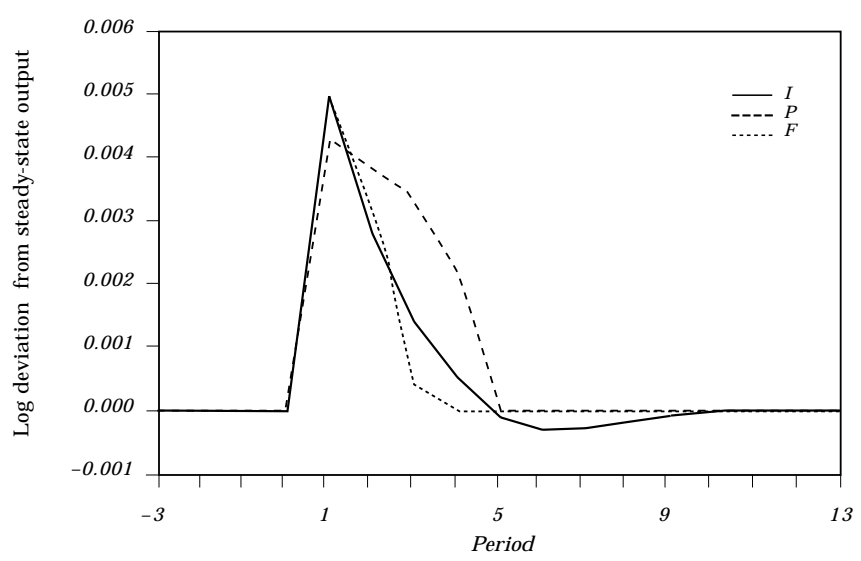

Fixed exchange rate

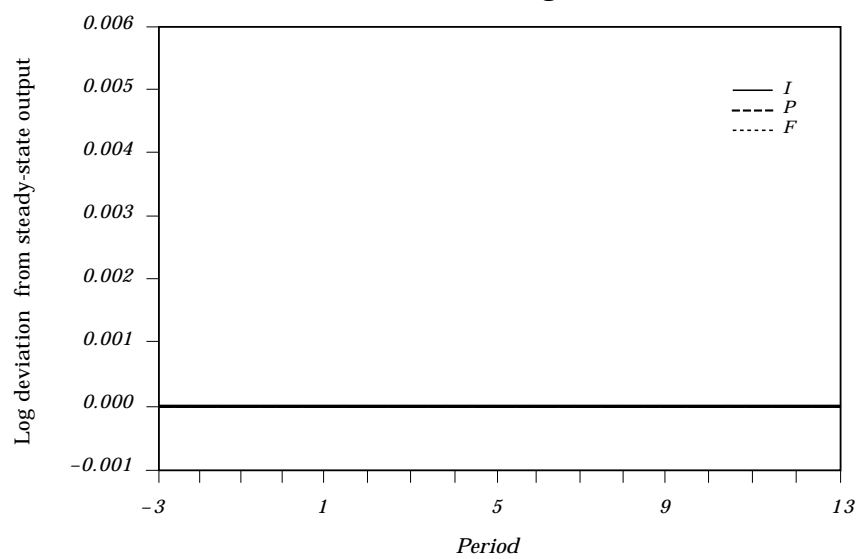


Figure 9. Output Effects of a Demand Shock in an Open Economy

Floating exchange rate

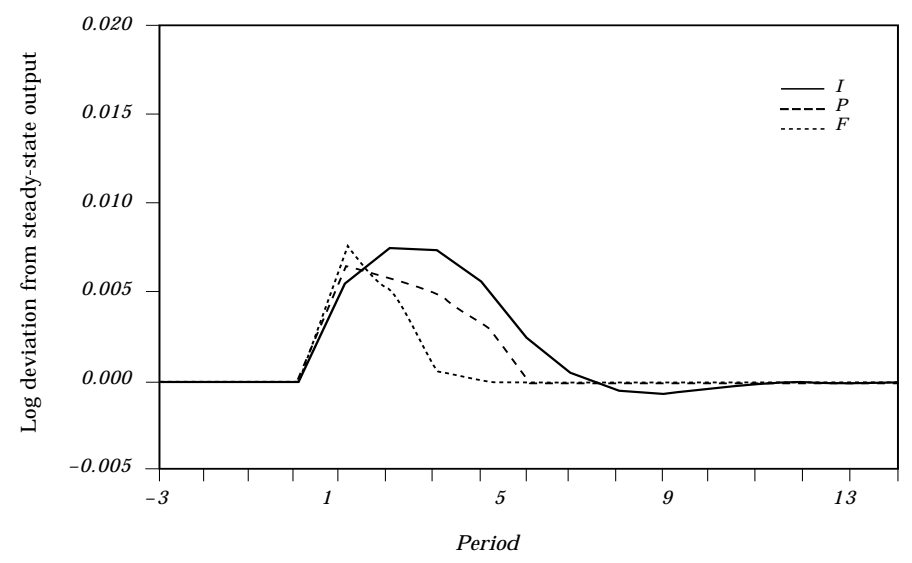

Fixed exchange rate

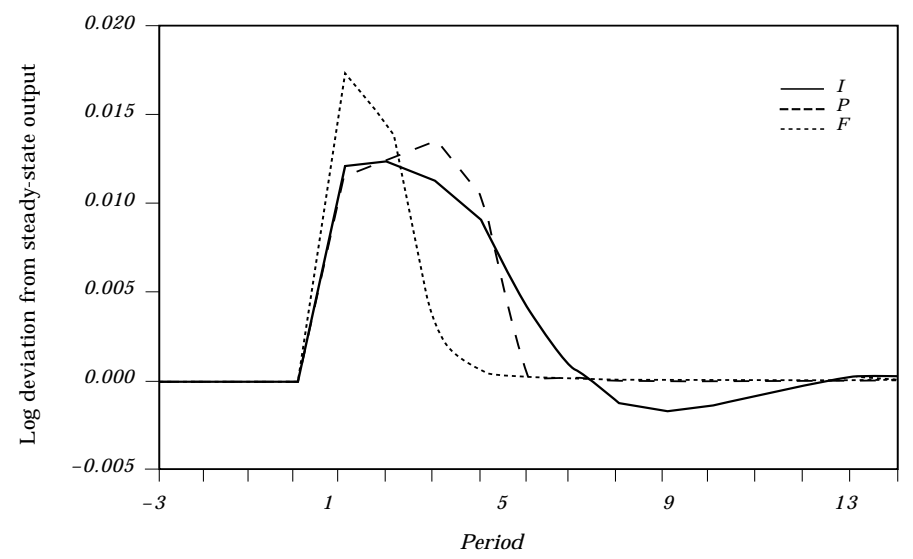

contracts, the increase in demand causes a temporary boom in output. Moreover, in line with the Mundell-Fleming results, the magnitude of this boom is significantly smaller when the exchange rate floats than when the exchange rate is fixed. The reason is that the long-term real appreciation required by the economy in order to accommodate the demand shock is attained differently depending on the exchange rate regime. With a fixed exchange rate, the real appreciation is achieved through an increase in wages 
and inflation in the periods following the shock. This process temporarily reduces expected real interest rates and achieves the real appreciation only gradually; these effects work to destabilize output during the period of adjustment. With a floating exchange rate, in turn, most of the required real appreciation is attained through a nominal appreciation at the time of the shock. This nominal appreciation helps to stabilize output, both by shifting demand out of the domestic good more quickly and by putting less pressure on wages and inflation as a vehicle for adjustment, which helps to stabilize expected real interest rates.

For this paper, the most important result is that the order of magnitude of the output boom caused by the demand shock does not depend on whether the wages are indexed or not. While the alternative types of wage contract under consideration do imply some differences in the behavior of output during the adjustment process, those differences are relatively minor, and they do not change the fact that a floating exchange rate substantially moderates the response of output to the shock. The relatively small effect of wage indexation on output behavior is again partly due to the fact that, regardless of the type of wage contract prevailing in the economy, wages are predetermined at the time the shock occurs. In addition, the top panel of figure 9 shows that the differences in the behavior of output are minor even when the different dynamics associated with the alternative types of contract are fully considered.

Does wage indexation have any tendency to destabilize the behavior of output in response to a demand shock when the exchange rate floats and to stabilize it when the exchange rate is fixed? In the case of a floating exchange rate, the top panel of figure 8 and the simulations for alternative parameter values in Jadresic (1998) indicate that wage indexation does tend to destabilize output. In this case, and for almost all parameter values considered, the variance of output with indexed wage contracts is larger than with preset time-varying wage contracts and with short-term fixed wage contracts. The reason is that in the periods immediately after the shock occurs, the indexation clauses quickly feed back into wages the lower inflation due to the initial appreciation, which tends to curb or even reduce them. This effect works first to moderate the magnitude of the real appreciation and then to reduce the expected real interest rate, as demanders anticipate that wages and inflation will have to accelerate in the future in order to compensate 
the unnecessary cutback of current wages. Consequently, with a floating exchange rate, the output boom caused by the demand shock tends to persist longer when contracts are indexed, which destabilizes output.

In the case of a fixed exchange rate, the analysis in Jadresic (1998) indicates that wage indexation has no clear-cut effect on the output response to a demand shock. Two parameters that are especially important in determining whether wage indexation raises or reduces this response are the elasticities of the demand for the domestic good with respect to the expected real interest rate and with respect to the real exchange rate. This is because wage indexation slows down the adjustment of wages and inflation, which tends to moderate the initial fall in expected real interest rates but to reduce the speed of the real appreciation required to reestablish equilibrium. While the former effect is stabilizing, the latter is destabilizing. Depending on the specific elasticities of the demand for the domestic good, wage indexation can either stabilize or destabilize output.

Jadresic (1998) also considers the effects of price shocks and productivity shocks. The analysis confirms that the effects of wage indexation to lagged inflation on output behavior are relatively small. Also, the results indicate that wage indexation is likely to destabilize output when shocks are in prices and that it has an ambiguous effect when shocks are in productivity.

To summarize, once the lags in actual indexation are taken into account, wage indexation in the open economy affects the behavior of output substantially less than posited in the previous literature. Also, the net effects of wage indexation on output stability in this context are ambiguous. For instance, if the economy is hit mainly by price shocks, wage indexation is likely to destabilize output. The same is bound to happen if the economy is hit mostly by shocks in the demand for goods and there is a floating exchange rate. However, if the economy is hit mainly by monetary or productivity shocks, or if it is hit mainly by demand shocks and there is a fixed exchange rate, the net effects of wage indexation are ambiguous and depend on the economy's parameter values. The overall implication is that a definite evaluation of the net effects of wage indexation on output stability in the open economy requires a precise specification of the economy under consideration, an issue which requires further research. 


\section{Further Macroeconomic Consequences of WAGE INDEXATION}

The previous sections focused on the consequences of wage indexation for the behavior of output. The above analysis, however, also has implications on other variables and issues. This section explores some of those implications, comparing them with the implications of the standard approach in the academic literature.

\subsection{The Choice of Exchange Rate Regime}

Building on models in which wage indexation is based on current inflation, the indexation literature infers that wage indexation would be a powerful reason to prefer a flexible exchange rate regime over a fixed exchange rate regime. This result has come out under the traditional approach in which the policymakers are assumed to be concerned only with output stabilization, as well as under the more modern approach in which the policymakers are assumed to be concerned with maintaining low inflation along with output stability, but in which their preferences are time inconsistent and exhibit an inflation bias. The crux of the argument is that wage indexation helps to protect output from monetary shocks regardless of the exchange rate regime in place. If this effect is true, wage indexation makes a fixed exchange rate unnecessary for dealing with monetary shocks and reduces the incentives to create inflationary surprises.

Consider first the traditional approach that evaluates exchange rate regimes according to the extent to which they help to stabilize output. While it is obviously recognized that anything can happen in the more general case of an arbitrary degree of indexation, the literature shows that with optimal wage indexation, in which the degree of indexation is optimally chosen to minimize the deviations between the actual and the frictionless level of output, a floating exchange rate regime is always better or at least as good as a fixed exchange rate regime. ${ }^{19}$ This result hinges on the prediction that

19. This proposition is put forth by Flood and Marion (1982), and Aizenman and Frenkel (1985a, b, 1986). The latter also show that around the optimal degree of wage indexation, a higher degree of indexation raises the optimal degree of exchange rate flexibility. In addition, they show that the concept of optimal wage indexation based on the minimization of the expected squared discrepancy of actual output from its frictionless level is equivalent to a concept of optimal wage indexation based on the minimization of the welfare cost of the distortions existing in the labor market. 
wage indexation helps to protect output from monetary shocks regardless of the exchange rate regime in place. If this effect is true, wage indexation clearly weakens the key merit of a fixed exchange rate regime under the criterion of output stabilization.

Wage indexation would also be a strong reason for preferring a flexible exchange rate regime if policymakers are concerned with maintaining low inflation along with output stability. This issue has been examined using a Barro and Gordon (1983) framework in which the policymakers' preferences are time inconsistent and exhibit an inflationary bias. In such a context and in the absence of wage indexation, it is generally accepted that a fixed exchange rate can perform better than a flexible exchange rate; this result requires that the fixed exchange rate increase the credibility of low inflation and that the benefits of this improved credibility outweigh the costs of losing flexibility to adjust to aggregate shocks. ${ }^{20}$ In contrast, the indexation literature shows that if the degree of wage indexation is optimal in the sense explained above, a flexible exchange rate regime generally gives better results than a fixed exchange rate regime. ${ }^{21} \mathrm{As}$ in the previous paragraph, this result also hinges on the prediction that wage indexation helps to protect output from monetary shocks. To the extent that this effect is true, wage indexation obviously reduces the incentives to create inflationary surprises and thus weakens the usefulness of the credibility effect associated with a fixed exchange rate regime.

Despite the faultless logic of the above arguments, the conclusion that wage indexation makes a flexible exchange rate generally preferable over a fixed exchange rate is unwarranted once the lags in actual indexation rules are taken into account. As is clear from the argument, that proposition depends crucially on the premise that wage indexation protects output from monetary shocks even when the exchange rate is flexible. As is also clear from the analysis in the previous sections, such a premise does not conform with the results obtained above, at least as a general or significant proposition.

20. This result can be formally derived by applying Barro and Gordon's (1983) analysis of inflationary bias with discretionary policy in an open economy context. See, for instance, Alogouskofis (1994); Obstfeld and Rogoff (1996).

21 . This result is due to Rasmussen (1993). It requires the condition that wage setters care about inflation at least as much as the policymakers do. 
What, then, are the general implications of the analysis on the choice of exchange rate regime? The broad similarity of the behavior of output with and without wage indexation suggests that the choice of exchange rate regime in economies with wage indexation depends on the same type of factors that affect the choice of exchange rate regime in economies without wage indexation. For instance, wage indexation seems unlikely to significantly alter the possible tradeoff between credibility of low inflation and flexibility in dealing with aggregate shocks, which part of the literature attributes to the choice between a fixed and flexible exchange rate. Therefore, while considering the existence of wage indexation does not help solve the longstanding problem of which exchange rate regime is optimal, it also does not appear to be a crucial factor in deciding the optimal regime. This suggested implication contrasts sharply with the suggestion of the academic literature that wage indexation generally makes a flexible exchange rate preferable.

A corollary of the above is that the existence of wage indexation is unlikely to be a good reason for implementing an indexed exchange rate regime. This is confirmed in Jadresic (1998), which finds that regardless of the type of contract in the economy, the effects of such a regime on output and real exchange rate stability are broadly similar to those of presetting the path for the exchange rate. In the end, with or without wage indexation, the main distinctive effect of an indexed exchange rate regime seems to be its well-known adverse effect on inflationary stability.

\subsection{The Level and Variability of Inflation}

The fact that actual indexation is with respect to lagged rather than current inflation also has implications for the determination of the level and variability of inflation. This section explores these implications.

Whether and how wage indexation affects the level of inflation depends on the factors that determine monetary policymaking. The literature typically analyzes this issue in the context of Barro and Gordon's (1983) model, under the assumption that the monetary authority has time-inconsistent preferences and cannot credibly commit to maintaining low inflation. Within this framework, the academic research has been ambiguous regarding the effects of wage indexation on the level of inflation. On the one hand, authors 
who accept the standard assumption that wage indexation is based on current inflation and that it thus stabilizes output when shocks are nominal generally assume that introducing wage indexation reduces the incentives to create nominal surprises and therefore reduces the level of inflation (for instance, see Fischer and Summers, 1989; Milesi-Ferretti, 1994; Crosby, 1995). On the other hand, while not questioning that wage indexation has this anti-inflationary effect, Ball and Cecchetti (1991) argue that this effect is more than offset by the fact that wage indexation mitigates the cost of inflation, which is inflationary.

Once the lags in actual wage indexation are considered, wage indexation seems relatively more likely to increase the level of inflation. Indeed, the findings discussed above indicate that when cost-of-living adjustments are based on lagged inflation, the standard assumption that wage indexation protects output from nominal shocks is unwarranted: wage indexation to lagged inflation can increase the response of output to a nominal shock, and, more generally, it modifies the shock's effect on output substantially less than is assumed in the literature. Consequently, wage indexation to lagged inflation is not necessarily a deterrent to the creation of nominal surprises, and when it is, it certainly is not as strong as wage indexation to current inflation. Given that wage indexation also diminishes the cost of inflation and reduces the will to fight inflation, then wage indexation seems relatively more likely to raise the inflation level. Of course, this presumption is conditional on the postulate that the monetary authority cannot credibly commit to maintaining low inflation, which is controversial (for instance, see McCallum, 1999).

Regarding the variability of inflation, Gray (1976) and Fischer (1977) argue that wage indexation increases price variability; this result implies larger inflation variability, at least in their basic models. In contrast, Jadresic $(1998,2002)$ finds that the effects of wage indexation is ambiguous. For instance, in a closed economy with a fixed money supply, wage indexation raises inflation variability when indexed wage contracts are compared to preset time-varying wage contracts, but it can either raise or lower inflation variability when indexed wage contracts are compared to short-term fixed wage contracts. In simulations with an open economy, in turn, it appears that wage indexation can similarly reduce inflation variability, but there is no guarantee that this is always the case. 


\section{Summary and Concluding Remarks}

This paper has reviewed the macroeconomic consequences of wage indexation, drawing on recent research by the author. In line with standard indexation rules, and in contrast to the previous academic literature, this research treats wage indexation explicitly as a clause in long-term contracts that grants periodic wage adjustments according to lagged inflation. To evaluate the consequences of contracts with this type of clauses, the paper models the behavior of the economy in the absence of indexation using two alternative standards of reference, namely, contracts that specify preset time-varying wages and short-term contracts that specify fixed wages.

Table 3 summarizes some of the main consequences of wage indexation to lagged inflation, contrasting the results of this analysis

\section{Table 3. Summary of the Macroeconomic Consequences of Wage Indexation}

\begin{tabular}{|c|c|c|}
\hline \multirow[b]{2}{*}{ Macroeconomic indicator } & \multicolumn{2}{|c|}{ Type of wage indexation } \\
\hline & Tocurrent inflation & To lagged inflation \\
\hline \multicolumn{3}{|l|}{ Cost of disinflation } \\
\hline $\begin{array}{l}\text { Money-based } \\
\text { stabilization }\end{array}$ & Reduces cost & $\begin{array}{l}\text { Reduces cost if nonindexed contracts } \\
\text { specify preset time-varying wages; } \\
\text { increases cost if nonindexed contracts } \\
\text { specify fixed wages }\end{array}$ \\
\hline $\begin{array}{l}\text { Exchange-rate- } \\
\text { based stabilization }\end{array}$ & Reduces cost & $\begin{array}{l}\text { Reduces cost if nonindexed contracts } \\
\text { specify preset time-varying wages; } \\
\text { increases cost if nonindexed contracts } \\
\text { specify fixed wages }\end{array}$ \\
\hline $\begin{array}{l}\text { Output stability } \\
\text { Closed economy }\end{array}$ & $\begin{array}{l}\text { Depends on the variance of } \\
\text { real and nominal shocks }\end{array}$ & Reduces stability \\
\hline Open economy & Ambiguous & Ambiguous \\
\hline $\begin{array}{l}\text { Choice of exchange } \\
\text { rate regime }\end{array}$ & Prefer flexible exchange rate & $\begin{array}{l}\text { Choice similar with or without } \\
\text { indexation }\end{array}$ \\
\hline Level of inflation ${ }^{b}$ & Ambiguous & $\begin{array}{l}\text { Ambiguous, but relatively more likely } \\
\text { to increase inflation }\end{array}$ \\
\hline Variability of inflation & Increases & Ambiguous \\
\hline
\end{tabular}

a. With fixed money supply.

b. If the monetary authority cannot credibly commit to maintaining low inflation. 
with the predictions of the standard approach that assumes that wage indexation is based on current inflation. The details that underlie the construction of this table have already been discussed throughout the paper and in the references there provided. For the record, the result that the effects of wage indexation on the cost of disinflation under exchange-rate-based stabilization are likely to be qualitatively similar to those under money-based stabilization is new.

An important lesson that emerges from this summary and comparison is that the standard analysis of wage indexation in the academic literature can provide a very misleading picture of the consequences of the typical type of wage indexation observed in real life. This finding should not be very surprising. As soon as one recognizes that standard wage indexation rules define a nominal rather than a real rigidity, it becomes apparent that the effects of wage indexation can differ considerably from those predicted by the assumption that wage indexation is based on current inflation. The research reviewed in this paper goes beyond this general statement, however, by showing that the assumption that wages are indexed to current inflation is of little usefulness even as a gross approximation of the issue. Table 3 indicates that in most of the issues examined, the macroeconomic consequences of wage indexation to lagged inflation are substantially different from the consequences of wage indexation to current inflation, even at a qualitative level.

The broad picture that emerges from taking into account the lags in actual wage indexation validates the views that most policymakers and applied observers seem to have on the consequences of wage indexation. The analysis indicates that wage indexation to lagged inflation can increase the cost of disinflation, destabilize output regardless of the types of shock in the economy, and matter relatively little for the choice of exchange rate regime. The analysis further suggests that unless policymakers are firmly committed to maintaining low inflation, wage indexation to lagged inflation is relatively more likely to increase average inflation. However, the analysis also indicates that there are important qualifications to be made with respect to these propositions.

In particular, wage indexation to lagged inflation can reduce the cost of disinflation if the alternative to indexed wage contracts are contracts that specify preset time-varying wages. Also, in an open economy and for a given policy regime, wage indexation to lagged inflation can increase or reduce output stability depending on the specific characteristics of the economy under consideration. A definite evaluation of what is the more relevant case in practice requires further research. 


\section{REFERENCES}

Adams, C., and D. T. Coe. 1990. "A Systems Approach to Estimating the Natural Rate of Unemployment and Potential Output for the United States." IMF Staff Papers 37(2): 232-93.

Aizenman, J. 1987. "Wage Indexation." In The New Palgrave: A Dictionary of Economics, edited by J. Eatwell, M. Milgate, and P. Newman, 838-40. London: Macmillan.

Aizenman, J., and J. A. Frenkel. 1985a. "On the Tradeoff between Wage Indexation and Foreign Exchange Intervention." Weltwirtschaftliches Archiv 121: 1-17. tervention, and Monetary Policy." American Economic Review 75(3): 401-23.

1986. "Wage Indexation, Supply Shocks, and Monetary Policy in a Small, Open Economy." In Economic Adjustment and Exchange Rates in Developing Countries, edited by S. Edwards and L. Ahamed, 89-129. University of Chicago Press for the National Bureau of Economic Research.

Alogouskofis, G. 1994. "On Inflation, Unemployment, and the Optimal Exchange Rate Regime." In The Handbook of International Macroeconomics, edited by F. Van der Ploeg, 192-223. Cambridge, Mass.: Basil Blackwell.

Argy, V. 1990. "Choice of Exchange Rate Regime for a Smaller Economy: A Survey of Some Key Issues." In Choosing an Exchange Rate Regime: The Challenge for Smaller Industrial Countries, edited by V. Argy and P. De Grauwe, 6-81. Washington: International Monetary Fund.

Ball, L. 1990. "Credible Disinflation with Staggered Price Setting." NBER Working Paper 3555. Cambridge, Mass.: National Bureau of Economic Research.

Ball, L., and S. Cecchetti. 1991. "Wage Indexation and Discretionary Monetary Policy.” American Economic Review 81(5): 1310-19.

Barro, R. J., and D. B. Gordon. 1983. "A Positive Theory of Monetary Policy in a Natural Rate Model." Journal of Political Economy 91 (April): 589-610.

Blanchard, O. J., and S. Fischer. 1989. Lectures on Macroeconomics. MIT Press.

Blanchard, O. J., and L. F. Katz. 1997. "What We Know and Do Not Know about the Natural Rate of Unemployment." Journal of Economic Perspectives 11(1): 51-72. 
Blanchflower, D. G., and A. J. Oswald. 1995. "An Introduction to the Wage Curve." Journal of Economic Perspectives 9(3): 153-67.

Bonomo, M., and R. García. 1994. "Indexation, Staggering and Disinflation." Journal of Development Economics 43: 39-58.

Carmichael, J., J. Fahrer, and J. Hawkins. 1986. "Some Macroeconomic Implications of Wage Indexation: A Survey." In Inflation and Unemployment: Theory, Experience, and Policy-Making, edited by V. E. Argy and J. W. Nevile, 78-102. London: G. Allen and Unwin.

Crosby, M. 1995. "Wage Indexation and the Time Consistency of Government Policy." Scandinavian Journal of Economics 97(1): 105-21.

Devereux, M. 1994. "Wage Indexation, Adjustment, and Inflation." In Labor Market in an Era of Adjustment, edited by S. Horton, R. S. M. Ravi, and D. Mazumdar, vol. 1, 195-236. Washington: World Bank.

Dornbusch, R. 1976. "Expectations and Exchange Rate Dynamics." Journal of Political Economy 84 (December): 1161-76.

-1982. "Stabilization Policy in Developing Countries: What Have We Learned?" World Development 10(9): 701-8.

Edwards, S. 1996. "A Tale of Two Crises: Chile and Mexico." NBER Working Paper 5794. Cambridge, Mass.: National Bureau of Economic Research.

Fischer, S. 1977. "Wage Indexation and Macroeconomic Stability." Carnegie-Rochester Conference Series on Public Policy 5: 107-48.

— 1985. "Contracts, Credibility, and Disinflation." In Inflation and Unemployment: Theory, Experience, and Policy-Making, edited by V. E. Argy and J. W. Nevile. London: George Allen and Unwin.

- 1988. "Real Balances, the Exchange Rate and Indexation: Real Variables in a Disinflation." Quarterly Journal of Economics 103(1): 27-49.

Fischer, S., and L. Summers. 1989. "Should Governments Learn to Live with Inflation?" American Economic Review 79(2): 382-87.

Fleming, J. M. 1962. "Domestic Financial Policies under Fixed and under Floating Exchange Rates." IMF Staff Papers 9 (November): 369-79.

Flood, R. P., and N. P. Marion. 1982. "The Transmission of Disturbances under Alternative Exchange Rate Regimes with Optimal Indexing." Quarterly Journal of Economics 97(1): 43-66. 
Friedman, M. 1974. "Monetary Correction." In Essays on Inflation and Indexation, edited by $\mathrm{H}$. Giersh and others. Washington, D.C.: American Enterprise Institute for Public Policy Research. García, P. S. 1995. "Mercado laboral y crecimiento: Chile 19801994 y proyecciones de mediano plazo." Colección Estudios CIEPLAN 40: 39-70. Santiago.

Genberg, H. 1989. "Exchange Rate Management and Macroeconomic Policy: A National Perspective." Scandinavian Journal of Economics 91(2): 439-69.

Gray, J. A. 1976. "Wage Indexation-A Macroeconomic Approach." Journal of Monetary Economics 2(2): 221-35.

Henderson, D.W., and W. J. McKibbin. 1993. "A Comparison of Some Basic Monetary Policy Regimes for Open Economies: Implications of Different Degrees of Instrument Adjustment and Wage Persistence." Carnegie-Rochester Conference Series on Public Policy 39 (December): 221-317.

Hendricks, W. E., and L. M. Kahn. 1985. Wage Indexation in the United States: Cola or Uncola. Cambridge, Mass.: Ballinger.

Kaufman, R. T., and G. Woglom. 1986. "The Degree of Indexation in Major U.S. Union Contracts." Industrial and Labor Relations Review 39(3): 439-48.

Jadresic, E. 1991. Wages, Indexation, and Aggregate Supply. Ph.D. dissertation, Harvard University.

. 1992. "Dinámica de salarios y contratos en Chile." Colección Estudios CIEPLAN 34 (June): 5-30. Santiago. For English version, see "What Type of Contracts Underlie Aggregate Wage Dynamics?" IMF Working Paper 67. Washington: International Monetary Fund.

. 1995. "Inflación, nivel de actividad y contratos salariales en Chile." In Análisis empírico de la inflación en Chile, edited by F. Morandé and F. Rosende. Santiago: Andros Productora Gráfica.

- 1996. "Wage Indexation and the Cost of Disinflation." IMF Staff Papers 43(4): 796-825.

- 1998. "Macroeconomic Performance under Alternative Exchange Rate Regimes: Does Wage Indexation Matter?" IMF Working Paper 118. Washington: International Monetary Fund. - 2002. "Wage Indexation and Output Stability Revisited." Journal of Credit, Money and Banking (forthcoming).

Landerretche, O., F. Lefort, and R. Valdés. 2002. "Causes and Consequences of Indexation: A Review of the Literature." This volume. 
Marston, R. C. 1982. "Wages, Relative Prices and the Choice between Fixed and Flexible Exchange Rates." Canadian Journal of Economics 15(1): 87-103.

. 1985. "Stabilization Policies in Open Economies." In Handbook of International Economics, edited by R. W. Jones and P. B. Kenen, vol. 2, 859-916. Amsterdam: North-Holland.

Maturana, V. 1992. "Los acuerdos salariales bajo negociaciones colectivas y la situación macroeconómica." Thesis, Pontificia Universidad Católica de Chile. Santiago.

McCallum, B. T. 1999. "Issues in the Design of Monetary Policy Rules." Handbook of Macroeconomics, edited by J. B. Taylor and M. Woodford. Amsterdam: North-Holland.

Milesi-Ferretti, G. M. 1994. "Wage Indexation and Time Consistency." Journal of Money, Credit and Banking 26(4): 941-50.

Mundell, R. A. 1963. "Capital Mobility and Stabilization Policy under Fixed and Flexible Exchange Rates." Canadian Journal of Economics and Political Science 29 (November): 475-85.

Morandé, F. G. 1985. "A Note on Wage Indexation in a Model with Staggered Wage Setting." Economics Letters 17: 19-22.

Obstfeld, M., and K. Rogoff. 1996. Foundations of International Macroeconomics. MIT Press.

Rasmussen, B. S. 1993. "Exchange Rate Policy, Union Wage Indexation, and Credibility." Journal of International Economics 35: 151-67.

Rebelo, S., and C. A. Végh. 1995. "Real Effects of Exchange RateBased Stabilization: An Analysis of Competing Theories." NBER Working Paper 5197. Cambridge, Mass.: National Bureau of Economic Research.

Riveros, L. A. 1996. "Adjustment, Inflation and Equity Effect: A Literature Survey on Wage Indexation." Unpublished paper. University of Chile. Santiago.

Rodriguez, C. A. 1982. "The Argentine Stabilization Plan of December 20th." World Development 10: 801-11.

Simonsen, M. H. 1983. "Indexation: Current Theory and the Brazilian Experience." In Inflation, Debt and Indexation, edited by R. Dornbusch and M. H. Simonsen, 99-132. MIT Press.

Taylor, J. B. 1980. "Aggregate Dynamics and Staggered Contracts." Journal of Political Economy 88(1): 1-23.

Turnovsky, S. J. 1983. "Wage Indexation and Exchange Market Intervention in a Small Open Economy." Canadian Journal of Economics 16(4): 574-92. 
1995. "Macroeconomic Stabilization Policy under Rational Expectations." In Methods of Macroeconomic Dynamics, 201-30. MIT Press.

Van Gompel, J. 1994. "Stabilization with Wage Indexation and Exchange Rate Flexibility." Journal of Economic Surveys 8(3): 251-81.

Williamson, J. 1985. "Concluding Appraisal." In Inflation and Indexation: Argentina, Brazil and Israel, edited by J. Williamson, 167-78. Washington: Institute for International Economics. 
